\title{
Arsenic Removal from Contaminated Water Using Natural Adsorbents: A Review
}

\author{
Kanfolo Franck Herve YEO ${ }^{1} \mathbb{D}$, Chaokun Li $^{1}$, Hui Zhang ${ }^{2}$, Jin Chen ${ }^{2}$, Wendong Wang ${ }^{1, *}$ and Yingying Dong ${ }^{1}{ }^{1 D}$ \\ 1 School of Human Settlements and Civil Engineering, Xi'an Jiaotong University, Xi'an 710049, China; \\ yeofranck@hotmail.com (K.F.H.Y.); lichaokun@stu.edu.xjtu.cn (C.L.); dyying@hotmail.com (Y.D.) \\ 2 School of Environmental and Municipal Engineering, Xi'an University of Architecture and Technology, \\ Xi'an 710055, China; zhanghui@xauat.edu.cn (H.Z.); jinchen@xauat.edu.cn (J.C.) \\ * Correspondence: wdwang@xjtu.edu.cn
}

Citation: YEO, K.F.H.; Li, C.; Zhang, H.; Chen, J.; Wang, W.; Dong, Y. Arsenic Removal from Contaminated Water Using Natural Adsorbents: A Review. Coatings 2021, 11, 1407. https://doi.org/10.3390/ coatings 11111407

Academic Editors: Filippo Berto, Ricardo Branco and Yanxin Qiao

Received: 12 October 2021

Accepted: 3 November 2021

Published: 19 November 2021

Publisher's Note: MDPI stays neutral with regard to jurisdictional claims in published maps and institutional affiliations.

Copyright: (c) 2021 by the authors. Licensee MDPI, Basel, Switzerland. This article is an open access article distributed under the terms and conditions of the Creative Commons Attribution (CC BY) license (https:// creativecommons.org/licenses/by/ $4.0 /)$.

\begin{abstract}
More than 170 million individuals have been influenced by arsenic (As) because of the ingestion of As-polluted groundwater. The presence of As in water bodies, particularly groundwater, has been found to become a widespread issue in the past few decades. Because arsenic causes extreme wellbeing impacts, even at a low concentration in drinking water, the innovations of As removal from contaminated water are of significant importance. Traditional strategies, for example, reverse osmosis, ion exchange, and electro-dialysis are generally utilized for the remediation of As-polluted water; however, the high cost and/or sludge production restricts their application in less-developed areas. The utilization of adsorbents acquired from natural materials has been explored as an alternative for the costly techniques for As removal. This paper aims to review the past and current developments in using naturals adsorbents or modified natural materials for arsenic removal and show the different parameters, which may influence the As removal effectiveness of the natural adsorbent, such as contact time, adsorbent dosage, flow rate, $\mathrm{pH}$, reusability, temperature, and influence of others ions.
\end{abstract}

Keywords: adsorption; arsenic; natural adsorbents

\section{Introduction}

The name arsenic (As) is thought to originate from the Syriac, Arabic, or Persian languages, and was later adopted into the Greek word arsenikon. The yellow-colored orpiment $\left(\mathrm{As}_{2} \mathrm{~S}_{3}\right)$ is infamous as the lord of all poisons. Arsenic (As) is an exceptionally harmful and cancer-causing metalloid that accounts for approximately $0.00005 \%$ of the Earth's outside layer. As ranks as the twentieth among the elements in abundance in the Earth's crust, fourteenth in the seawater, and twelfth in human body [1]. Arsenic occurs in rock soils, organisms, natural water, air, and in the other natural environments [2]. The element of As can form over 200 minerals in soil, and mainly exists as As(0), As(III), As(V), and arsenide. Besides, a high As concentration is found in numerous oxide minerals and hydrous metal oxides, either as a part of the mineral structure or as adsorbed species. The amount of As in sedimentary rocks ordinarily ranges from 5 to $10 \mathrm{mg} / \mathrm{kg}$, which is usually over the normal content in a terrestrial environment, approximately 1.5 to $3 \mathrm{mg} / \mathrm{kg}$ [3] A significant amount of As in natural water is also from anthropogenic sources, such as cosmetics, mining operations, coal combustion, smelting, pesticides, dyes, wood treatment, As trioxide stockpiles and paints. Arsenic is also highly soluble in water [4-6].

The two most prevailing types of As in aqueous environment are As(III) and As(V). Depending on the environment conditions, such as $\mathrm{pH}$, the redox condition, the microbial activity, and presence of complexing ions, the pentavalent As mainly consists of arsenate ions $\left(\mathrm{H}_{2} \mathrm{AsO}_{4}{ }^{1-}, \mathrm{HAsO}_{4}{ }^{2-}, \mathrm{AsO}_{4}{ }^{3-}\right)$ and arsenic acid $\left(\mathrm{H}_{3} \mathrm{AsO}_{4}\right)$. Similarly, the $\mathrm{As}(\mathrm{III})$ species may present as arsenite ions $\left(\mathrm{H}_{2} \mathrm{AsO}_{3}{ }^{1-}, \mathrm{HAsO}_{3}{ }^{2-}\right.$, and $\left.\mathrm{AsO}_{3}{ }^{3-}\right)$ and arsenious acid $\left(\mathrm{H}_{3} \mathrm{AsO}_{3}\right)$. The pentavalent species are the predominant species under aerobic con- 
ditions, such as surface water [7], whereas the trivalent species are the prevailing species under anoxic conditions, such as subsurface groundwater $[8,9]$.

\section{Harmful Effects of Arsenic}

$\mathrm{As}(\mathrm{III})$ and $\mathrm{As}(\mathrm{V})$ are both very toxic, with increased risk for cancer of the skin, lungs, urinary bladder, liver, and kidney [10], but As(III) is multiple times more harmful and versatile than $\mathrm{As}(\mathrm{V})$. Wellbeing impacts of arsenic rely upon different kind of parameters. These include the type and amount of arsenic that has been swallowed, how long you have been exposed to arsenic, and how the body reacts to arsenic. Unborn infants, children, and people with long sicknesses and the elderly are the weakest to arsenic exposure. The impacts of arsenic, when ingested even in limited quantities, show up gradually; it might take quite a long while for the harming effects to become obvious.

Arsenic pollution in natural water is an overall issue, and has become a significant issue and challenge for world specialists, researchers, and even politicians. For instance, persistent arsenic poisoning due to drinking arsenic-polluted water has been one of the terrible wellbeing impacts influencing eight areas of West Bengal since the mid 1980s. Itemized clinical assessment and investigation of 248 such patients showed the clinical signs of such harmfulness. Well beyond hyperpigmentation and keratosis, powerlessness, paleness, painful eyes, leg swelling, liver fibrosis, persistent lung ailment, gangrene of toes, neuropathy, and skin malignant growth were a portion of different symptoms [11]. The World Health Organization (WHO) and the U.S. Environmental Protection Agency (US EPA) have limited the As concentration level at $10 \mu \mathrm{g} / \mathrm{L}$ in 2001.

\section{Arsenic Removal Technology}

Considering the danger of As in water, especially in drinking water, many approaches have been studied for As removal. Traditionally, there are a few techniques including membrane filtration, coagulation and flocculation, electrochemical techniques, bioremediation, ion or particle exchange, and adsorption utilized in arsenic removal [12-15].

\subsection{Membrane Filtration}

Membrane filtration is most commonly used to eliminate arsenic from water. Membrane films are regularly manufactured materials with billions of pores or minute openings that operate as a specific obstruction; the structure of membrane permits a few constituents to go through, while others are avoided or dismissed. The different kinds of membrane filtration can be divided into four techniques: ultrafiltration membranes are usually with 0.0003 to 0.1 microns for colloids, viruses, and certain proteins removal [16]; nanofiltration with 0.001 to 0.003 microns for physical removal based on both charge and molecular size; microfiltration with 0.1 micron for bacteria and suspended solids removal [17]; and hyperfiltration or reverse osmosis with 0.0005 microns for desalinization [18].

\subsection{Coagulation}

Many studies have showed that coagulation can be used for removing arsenic from contaminated water by the addition of a coagulant in the arsenic solution. This process can also remove many other suspended and dissolved constituents from water, such as fluoride, manganese, iron, phosphate, and turbidity. This arsenic removal technique is profoundly reliant upon $\mathrm{pH}$, the valence of the arsenic species., dosage of coagulant, and the initial arsenic concentration [19].

\subsection{Electrochemical Techniques}

The utilization of electricity for waste water treatment started early, since 1887 in the United Kingdom [20]. There are a lot of different electrochemical techniques, including electrodeposition [21], electrocoagulation [22,23], electrodialysis [24], electroflotation [25], and electrooxidation [26] used for heavy metal removal. Electrocoagulation is a process using chemical and physical reactions in which sacrificial electrodes are used for the 
generation of coagulants. This process, needing a high amount of electricity, is the one used the most for arsenic removal from water.

\subsection{Bioremediation}

Some natural organisms, such as bacteria, algae, and plants especially the aquatic plants, have a capacity to amass trace elements (heavy metals), which allows them to be used for the treatment of polluted water from industrial or agrochemical discharges, especially contaminated with heavy metals $[27,28]$.

\subsection{Ion or Particle Exchange}

Ion exchange is a physical/chemical process in which particles held electrostatically on the outside of a solid phase are exchanged for particles of same charge in a solution (i.e., drinking water). The solid is ordinarily a synthetic or natural anion exchange resin, which is utilized to specially remove specific contaminants of concern. Ion exchange is generally utilized in drinking water treatment for softening (i.e., removal of magnesium, calcium, and other cations in exchange of sodium), as well as removing arsenate, nitrate, selenate, and chromate from municipal water [29].

\subsection{Adsorption}

Adsorption is a process that utilizes solids for eliminating substances from either liquid or gaseous solutions, by attraction on the solid's surface. Solids, such as synthetic materials (fibers, resins, activated carbon, metal hydrides, membranes) [30,31] or natural materials [32] are widely utilized in industrial application for wastewater treatment and purification. However, synthetic materials are expensive to be produced, as the production of them requires a lot of energy and is not environment friendly compared to natural materials.

As mentioned above, most processes have been proved to be effective in removing As from water. For example, As in water can be effectively removed after being blended with other metal oxides (iron or aluminum oxides) for a coagulation to change into the solid phase [33]. However, the high energy required (electrocoagulation), the high cost of their process (membrane filtration), and the non-environmentally friendly residue (coagulation and synthetic adsorbent adsorption) after the treatment processes, limit their application and lead researchers to conduct new research with naturals materials, which are ecological and cheaper to find [34-36]. In this paper, we reviewed the removal performances of As from contaminated drinking water/groundwater by adsorption using natural adsorbents and/or modified natural materials.

\section{Biosorbents}

Biosorbents (natural adsorbents) are made from natural materials, including natural fibers, volcanic rocks, soils, plant biomass, agricultural and industrial wastes, animal shells, microalgae, and fungal biomass (Figure 1). A common feature of these materials is that their large specific surface area, which is capable of physically retaining arsenic ions or molecules. In recent years, more and more natural adsorbents are used because of their higher arsenic removal capacity, reusability, and lower cost and environment impacts as compared with the other methods involving synthetics membranes and materials using significant chemical dosage [37,38]. Among all the natural materials, agricultural wastes, comprised of proteins, extractives, hemicellulose, lignin, lipids, starch, and simple sugars, contain more functional groups, which facilitate heavy metal retention [39-42]. In Table 1, some different natural adsorbents that have been used for As removal from water are listed. 

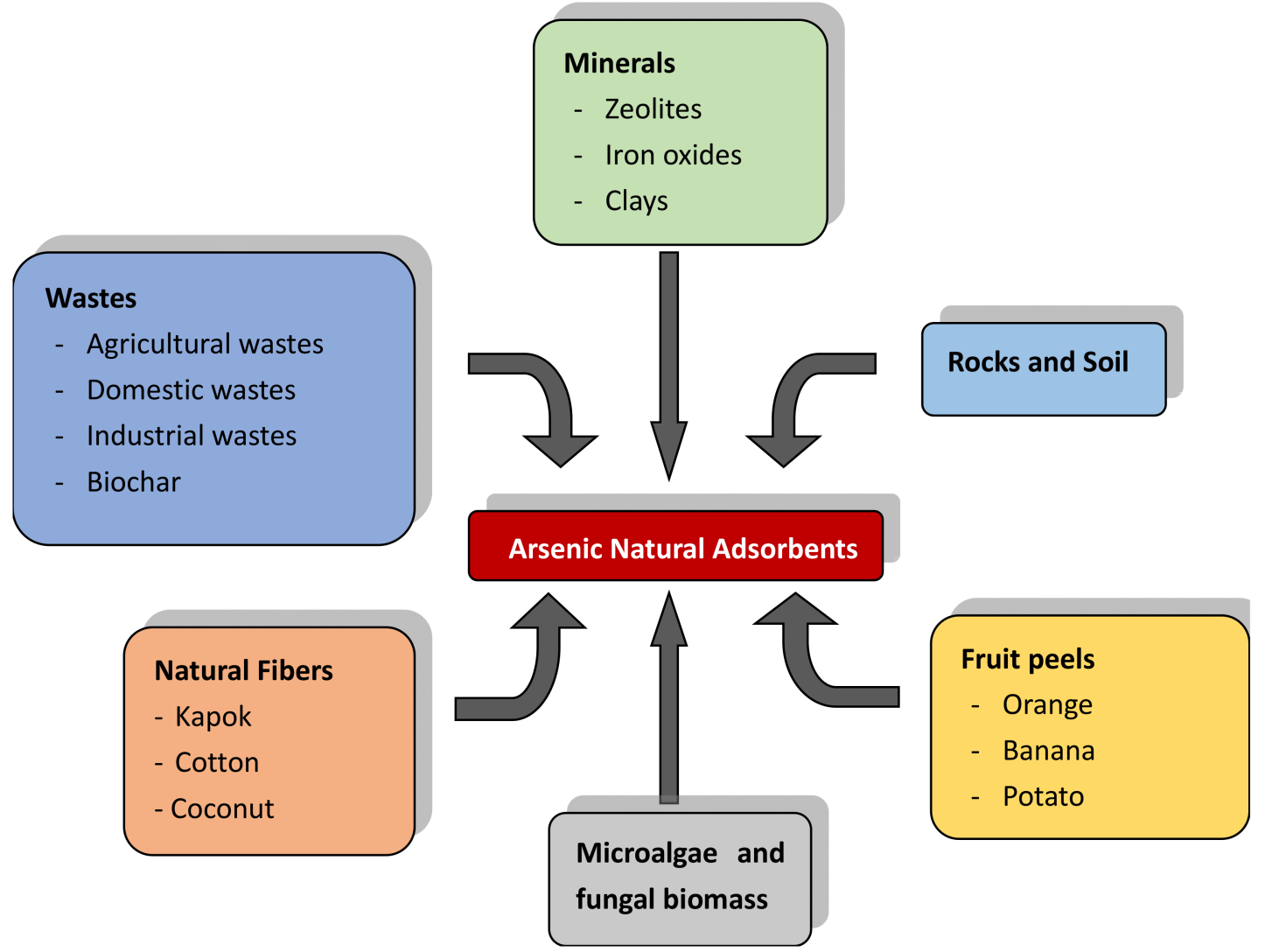

Figure 1. Different types of natural adsorbent As.

Table 1. Some As natural adsorbents and their adsorption capacities.

\begin{tabular}{|c|c|c|c|c|c|}
\hline \multirow{2}{*}{ Adsorbents } & \multirow{2}{*}{ Treatments } & \multirow{2}{*}{$\begin{array}{l}\text { Isotherm } \\
\text { Model Fit }\end{array}$} & \multirow{2}{*}{$\mathrm{pH}$} & \multicolumn{2}{|c|}{ Adsorption Capacities mg/g } \\
\hline & & & & As(III) & $\operatorname{As}(\mathrm{V})$ \\
\hline Wheat Straw [43] & $\mathrm{NaHCO}_{3}$ & Langmuir & 7 & No data & 0.097 \\
\hline Wheat Straw [44] & $\mathrm{FeSO}_{4}$ and $\mathrm{FeCl}_{3}$ & Langmuir & 6 & No data & 30.24 \\
\hline Black Tea [45] & No Treatments & $\begin{array}{l}\text { Freundlich and } \\
\text { Langmuir }\end{array}$ & 6 & No data & 1.76 \\
\hline G. cambogia fruits rinds [46] & IICT Technology & Langmuir & 6 & 128.10 & No data \\
\hline Coconut Fibers [47] & $\mathrm{HNO}_{3}$ and $\mathrm{NaOH}$ & Freundlich & 4 & 0.12 & No data \\
\hline Sugarcane bagasse [48] & $\left(\mathrm{Fe}\left(\mathrm{NO}_{3}\right)_{3} \cdot 9 \mathrm{H}_{2} \mathrm{O}\right)$ & Langmuir & 6 & 0.6 & No data \\
\hline Sawdust [49] & $\mathrm{Fe}(\mathrm{III})$ & Langmuir & 8 & No data & 5.8 \\
\hline Orange Peel [50] & No Treatments & Freundlich & 7 & No data & 4.8 \\
\hline Moringa Lamarck seed [51] & No Treatments & Langmuir & 8 & 1.5 & 2.1 \\
\hline Rice Husk [52] & No Treatments & Freundlich & 7 & 220.1 & No data \\
\hline Mango leaf powder [52] & No Treatments & Freundlich & 7 & 250.07 & No data \\
\hline Mosambi Citrus Peel [53] & No Treatments & Freundlich & 6 & 2.12 & 3.32 \\
\hline Rice straw [54] & $\mathrm{Fe}\left(\mathrm{NO}_{3}\right)_{3}$ & Langmuir & 4 & No data & 21.739 \\
\hline Rice husk [55] & $\mathrm{Fe}(\mathrm{III})$ & Langmuir & 4 & No data & 2.47 \\
\hline Corncob husk [56] & $\mathrm{FeCl}_{3}$ & Langmuir & 6 & 50 & No data \\
\hline
\end{tabular}


Table 1. Cont.

\begin{tabular}{|c|c|c|c|c|c|c|}
\hline \multirow{2}{*}{ Adsorbents } & \multirow{2}{*}{ Treatments } & \multirow{2}{*}{$\begin{array}{l}\text { Isotherm } \\
\text { Model Fit }\end{array}$} & \multirow{2}{*}{\multicolumn{2}{|c|}{$\mathrm{pH}$}} & \multicolumn{2}{|c|}{ Adsorption Capacities mg/g } \\
\hline & & & & & As(III) & As(V) \\
\hline Coconut coir pith (CP) [57] & $\begin{array}{l}\text { Epichlorohydrin and } \\
\text { dimethylamine }\end{array}$ & Langmuir & & & No data & 13.57 \\
\hline Groundnut shells [58] & No Treatments & Langmuir & & & 0.014 & No data \\
\hline Bead Cellulose (Cotton) [59] & $\left(\mathrm{FeCl}_{3} \cdot 6 \mathrm{H}_{2} \mathrm{O}\right)$ & Langmuir & 9 & 4 & 99.6 & 33.2 \\
\hline Sawdust [60] & $\mathrm{ZrOCl}_{2} \cdot 8 \mathrm{H}_{2} \mathrm{O}$ & Langmuir & 9 & 4 & 29 & 12 \\
\hline Rice husk [61] & Iron oxide & Langmuir & & & No data & 82 \\
\hline Paddy Husk Ash [62] & $\mathrm{AlCl}_{3} \cdot 6 \mathrm{H}_{2} \mathrm{O}$ & Freundlich & & & No data & 0.063 \\
\hline Zeolite stones [63] & $\mathrm{Al}_{2}\left(\mathrm{SO}_{4}\right) \cdot 16 \mathrm{H}_{2} \mathrm{O}$ & Freundlich & & & No data & 208 \\
\hline Iron oxide-coated sand [64] & $\mathrm{Fe}(\mathrm{III})$ & Langmuir & & & 28.57 & No data \\
\hline Goethite [65] & No treatment & No data & & & No data & 1 \\
\hline Iron-coated zeolite [66] & $\mathrm{FeCl}_{3}$ & Langmuir & & & No data & 0.68 \\
\hline $\begin{array}{l}\text { Iron-modified activated } \\
\text { carbon [67] }\end{array}$ & $\mathrm{Fe}\left(\mathrm{NO}_{3}\right)_{3} \cdot 9 \mathrm{H}_{2} \mathrm{O}$ & Langmuir & 8 & 6 & 43.6 & 51.3 \\
\hline
\end{tabular}

\section{Treatment of the Natural Adsorbents}

Some natural adsorbents without any kind of pre-treatment are good enough for removing As from water because of their surface structure composition, such as the acidic functional groups $(-\mathrm{SH},-\mathrm{COOH})$ present in the rice husk cellulose component or the $\mathrm{Fe}$ and $\mathrm{Al}$ oxide present on montmorillonite, kaolinite, and illite clay minerals as impurities (Figure 2). These functional groups may facilitate the interaction with As anions [68,69]. On the other hand, as we can see in the Table 1, some adsorbents need to be pre-treated to improve their As adsorption capacity. The goal of pre-treatment by washing and cleaning, using distilled water, alkali $(\mathrm{NaOH})$ or acidic $(\mathrm{HCl})$ solution is to remove impurity particles or add some functional group on the surface of the natural material. Therefore, pretreatment will make it possible to highlight the functional groups $\left(\mathrm{CH}_{3}-\mathrm{OH},-\mathrm{COOH}\right.$, $\left.\mathrm{CH}_{3}-\mathrm{NH}_{2}, \mathrm{Fe}(\mathrm{OH})_{3}, \mathrm{Al}(\mathrm{OH})_{3}\right)$, and therefore will facilitated the interactivity between natural adsorbents and As ions.

Distilled water is used most of the time to remove surface adhered impurity particles, water-soluble materials [57]. The distilled water washed materials will be dried under specific conditions as necessary, for example, coconut coir pith (CP) dried at $80^{\circ} \mathrm{C}$, groundnut shell dried under sun for 2 days [58], and rice husk dried at $60^{\circ} \mathrm{C}$ [70]. Alkali pre-treatment with $20 \% \mathrm{NaOH}$ solution is used to degrease cotton and add hydroxyl group onto the surface [59], and remove the lignin of sawdust [60]. Acidic pre-treatment selectively removes the organic base by converting it into a water-soluble salt as HCL $(10 \%)$, which is used to clean rice husk to remove all the impurities, then later crushed and dried at $500{ }^{\circ} \mathrm{C}$ in muffle furnace for $8 \mathrm{~h}$ [61], and Dialium guineense seed shells have been crushed then soaked in (40\%) phosphoric and nitric acid, then heated to a carbon activation temperature of $400{ }^{\circ} \mathrm{C}$ for $30 \mathrm{~min}$. 


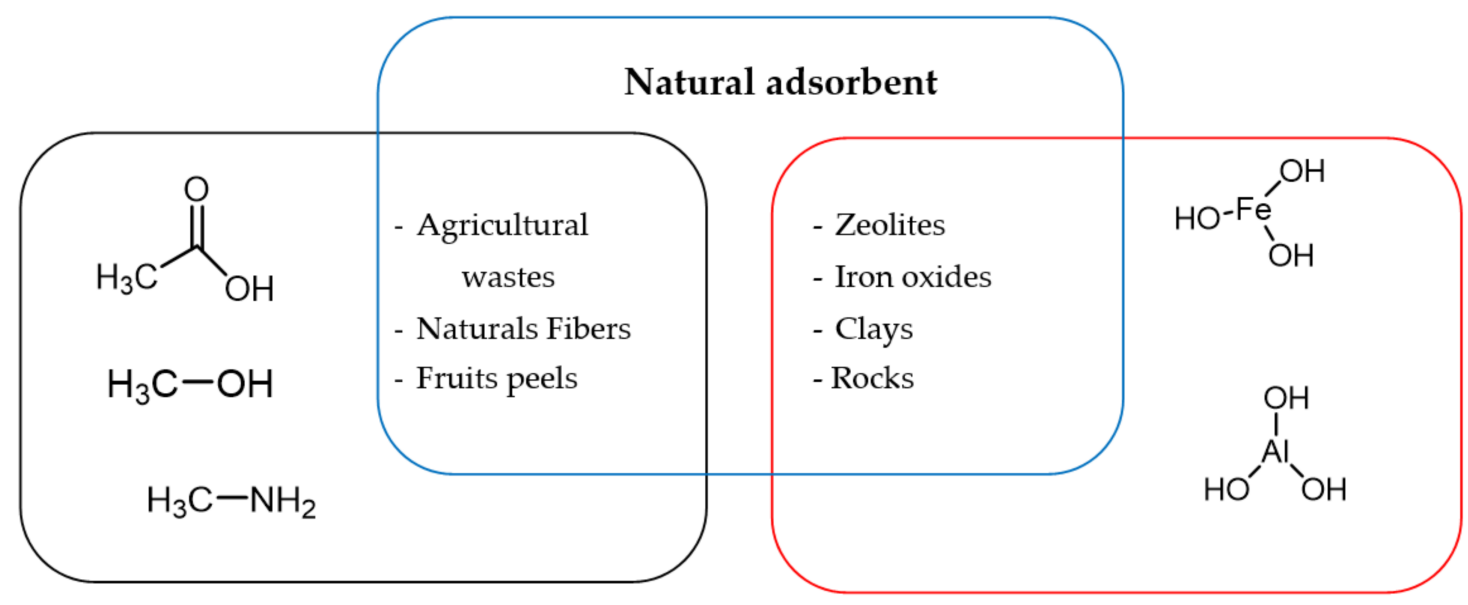

Figure 2. Functional groups existing on the surface of natural adsorbents.

The objective of the treatment is to change the surface structure, to improve the As removal capacity of natural adsorbents by adding essential functional groups $\left(\mathrm{Fe}^{3+}, \mathrm{Al}^{3+}\right.$, $\mathrm{TiO}_{2}$ ) [71-74]. Aluminum ions are often used for the modification of the natural adsorbent's surface, since $\mathrm{Al}^{3+}$ oxidative capacity towards $\mathrm{As}(\mathrm{III})$ is well known $[75,76]$. The reactions below might be the interaction of $\mathrm{As}(\mathrm{V})$ and $\mathrm{As}(\mathrm{III})$ with the natural asorbent $(\mathrm{M})$ after its surface modification with aluminum:

$\mathrm{As}(\mathrm{V})$

$$
\begin{gathered}
\mathrm{M}=\mathrm{Al}(\mathrm{OH})+\mathrm{H}_{3} \mathrm{AsO}_{4} \rightarrow \mathrm{M}=\mathrm{Al}-\mathrm{AsO}_{4} \mathrm{H}_{2}+\mathrm{H}_{2} \mathrm{O} \\
\mathrm{M}=\mathrm{Al}(\mathrm{OH})+\mathrm{H}_{2} \mathrm{AsO}_{4}{ }^{-} \rightarrow \mathrm{M}=\mathrm{Al}-\mathrm{HAsO}_{4}{ }^{-}+\mathrm{H}_{2} \mathrm{O} \\
\mathrm{M}=\mathrm{Al}(\mathrm{OH})+\mathrm{HAsO}_{4}{ }^{2-} \rightarrow \mathrm{M}=\mathrm{Al}-\mathrm{AsO}_{4}{ }^{2-}+\mathrm{H}_{2} \mathrm{O}
\end{gathered}
$$

As(III)

$$
\begin{gathered}
\mathrm{M}=\mathrm{Al}(\mathrm{OH})+\mathrm{H}_{3} \mathrm{AsO}_{3} \rightarrow \mathrm{M}=\mathrm{Al}-\mathrm{AsO}_{3} \mathrm{H}_{2}+\mathrm{H}_{2} \mathrm{O} \\
\mathrm{M}=\mathrm{Al}(\mathrm{OH})+\mathrm{H}_{2} \mathrm{AsO}_{3}{ }^{-} \rightarrow \mathrm{M}=\mathrm{Al}-\mathrm{HAsO}_{3}{ }^{-}+\mathrm{H}_{2} \mathrm{O} \\
\mathrm{M}=\mathrm{Al}(\mathrm{OH})+\mathrm{HAsO}_{3}{ }^{2-} \rightarrow \mathrm{M}=\mathrm{Al}-\mathrm{AsO}_{3}{ }^{2-}+\mathrm{H}_{2} \mathrm{O}
\end{gathered}
$$

For example, hydroxyl-alumina has been used as a surface activating agent for the modification of paddy husk ash particles, using $\mathrm{AlCl}_{3} \cdot 6 \mathrm{H}_{2} \mathrm{O}$ and aluminum fine powder [62]. The surface of crushed pumice and zeolite stone particles can be coated with aluminum ions by immersing pumice and zeolite stone particles in $0.5 \mathrm{M} \mathrm{Al}_{2}\left(\mathrm{SO}_{4}\right) \cdot 16 \mathrm{H}_{2} \mathrm{O}$ solution, and drying at room temperature for $72 \mathrm{~h} \mathrm{[63].} \mathrm{Similarly,} \mathrm{the} \mathrm{removal} \mathrm{of} \mathrm{As(V)} \mathrm{and}$ As(III) can be enhanced with the introduction of ferric ions on the surface of natural materials $(\mathrm{M})$ because of the formation of ferric arsenate $\mathrm{FeAsO}_{4} \cdot 2 \mathrm{H}_{2} \mathrm{O}$ at a low $\mathrm{pH}[67,77,78]$. The reactions below might be the interaction of $\mathrm{As}(\mathrm{V})$ and $\mathrm{As}(\mathrm{III})$ with the natural adsorbent (M) after its surface modification with iron:

$\mathrm{As}(\mathrm{V})$

$$
\begin{aligned}
& \mathrm{M}=\mathrm{Fe}(\mathrm{OH})+\mathrm{H}_{3} \mathrm{AsO}_{4} \rightarrow \mathrm{M}=\mathrm{Fe}-\mathrm{AsO}_{4} \mathrm{H}_{2}+\mathrm{H}_{2} \mathrm{O} \\
& \mathrm{M}=\mathrm{Fe}(\mathrm{OH})+\mathrm{H}_{2} \mathrm{AsO}_{4}{ }^{-} \rightarrow \mathrm{M}=\mathrm{Fe}-\mathrm{HAsO}_{4}{ }^{-}+\mathrm{H}_{2} \mathrm{O} \\
& \mathrm{M}=\mathrm{Fe}(\mathrm{OH})+\mathrm{HAsO}_{4}{ }^{2-} \rightarrow \mathrm{M}=\mathrm{Fe}-\mathrm{AsO}_{4}{ }^{2-}+\mathrm{H}_{2} \mathrm{O}
\end{aligned}
$$

As(III)

$$
\begin{gathered}
\mathrm{M}=\mathrm{Fe}(\mathrm{OH})+\mathrm{H}_{3} \mathrm{AsO}_{3} \rightarrow \mathrm{M}=\mathrm{Fe}-\mathrm{AsO}_{3} \mathrm{H}_{2}+\mathrm{H}_{2} \mathrm{O} \\
\mathrm{M}=\mathrm{Fe}(\mathrm{OH})+\mathrm{H}_{2} \mathrm{AsO}_{3}{ }^{-} \rightarrow \mathrm{M}=\mathrm{Fe}-\mathrm{HAsO}_{3}{ }^{-}+\mathrm{H}_{2} \mathrm{O} \\
\mathrm{M}=\mathrm{Fe}(\mathrm{OH})+\mathrm{HAsO}_{3}{ }^{2-} \rightarrow \mathrm{M}=\mathrm{Fe}-\mathrm{AsO}_{3}{ }^{2-}+\mathrm{H}_{2} \mathrm{O}
\end{gathered}
$$

Maji et al. [79] and Joshi et al. [80] found that the surface structure of crushed natural rock particles and river sand could be successfully modified using Fe(III) nitrate solution, 
then dried in $110-150{ }^{\circ} \mathrm{C}$ hot air; this finding was similar to Jeon C.S. et al. [66] using zeolite (clinoptilolite) as a natural material. In some cases, natural iron oxide minerals, such as magnetite $\left(\mathrm{FeOFe}_{2} \mathrm{O}_{3}\right)$, hematite $\left(\mathrm{Fe}_{2} \mathrm{O}_{3}\right)$, goethite $(\mathrm{FeO}(\mathrm{OH}))$, and laterite, were used directly for As adsorption from water without any pre-treatment or treatment [65].

\section{As Removal Performance}

Many researches have been conducted to evaluate the As adsorption performance of many different types of natural adsorbents, by studying the effects of different factors [81]. There are many parameters that can influence the removal capacity of the natural adsorbents, such as $\mathrm{pH}$, initial dosage of the adsorbents, initial concentration of the As solution, contact time, temperature, and the effect of other ions in the water solution. The natural adsorbent for As removal has mainly been tested by using two different methods, batch test and column test [82-86].

\subsection{Overall Adsorption Performance}

To achieve an efficient As removal from water, both the initial As concentration and adsorbent dosage are optimized before conduction water treatment $[87,88]$. As can be seen in the Table 2, it is obvious that an increase in the initial As concentration leads to a decrease in the As removal efficiency $[89,90]$. Usually, As removal efficiency increases with the increase in the adsorbent's dosage, due to the higher surface area or exchangeable sites provided. However, if the adsorbent's dosage is too high, the removal efficiency of As will finally stay constant, which is not economic [91-94]. Take iron-modified peat for example, it was determined that only $60 \%$ of the $\mathrm{As}(\mathrm{V})$ was removed with an initial concentration of $800 \mathrm{mg} \cdot \mathrm{L}^{-1}$, and the ratio reached more than $90 \%$ when its initial concentration decreased to $300 \mathrm{mg} \cdot \mathrm{L}^{-1}[95,96]$. Compared with iron-modified peat, PAC-500 (peels activated carbon) and PPAC-500 (pulps activated carbon) seem to have a lower As adsorption capacity. It was determined that when the initial concentration of As was around $2.5 \mathrm{mg} / \mathrm{L}$, less than $80 \%$ of As was removed, and this ratio would be above $95 \%$ when the initial concentration of As decreased to around $0.5 \mathrm{mg} / \mathrm{L}$ [97]. Again, considering only $40-50 \%$ of As was adsorbed when its initial concentration was in the range of $0.005-0.02 \mathrm{mg} / \mathrm{L}$, modified clinoptilolite zeolite (MCZ) seems have the lowest As adsorption capacity [98].

Table 2. Some studies related to initial As concentration and adsorbent dosage impact on As adsorption capacity.

\begin{tabular}{|c|c|c|c|c|c|}
\hline \multirow{2}{*}{ Adsorbent } & \multirow{2}{*}{$\begin{array}{l}\text { Adsorbent } \\
\text { Dosage (g) }\end{array}$} & \multirow{2}{*}{$\begin{array}{l}\text { Solution } \\
\text { Quantity } \\
(\mathrm{mL})\end{array}$} & \multirow{2}{*}{$\begin{array}{c}\text { Intial } \\
\text { Concentration } \\
(\mathrm{mg} / \mathrm{L})\end{array}$} & \multicolumn{2}{|c|}{ Removal (\%) } \\
\hline & & & & As(V) & As(III) \\
\hline Peat-based sorbents [96] & 0.5 & 40 & $8-904$ & No data & $100-43$ \\
\hline Red mud-modified biochar (RM-BC) [87] & 0.12 & 30 & $1-50$ & $100-32$ & $50-4$ \\
\hline $\begin{array}{l}\text { Novel magnetic chitosan nanoparticle } \\
\text { (MCNP) [89] }\end{array}$ & 0.05 & 100 & $0.2-50$ & $100-65$ & $100-60$ \\
\hline Hematite Pinewood biochar (HPB) [99] & 0.05 & 20 & $1-50$ & $25-2$ & No data \\
\hline Modified clinoptilolite zeolite (MCZ) [98] & 1 & 200 & $0.005-0.05$ & $55-40$ & No data \\
\hline Iron-modified peat [96] & 0.5 & 40 & $100-270$ & $100-70$ & No data \\
\hline Biomass of Citrus limmeta (PPAC-500) [97] & 0.15 & 50 & $0.05-2.5$ & $100-62$ & $93-55.2$ \\
\hline Leaves of $P$. roxburghii powder [88] & $0.2-2$ & 50 & 10 & $4-75$ & No data \\
\hline Iron modified montmorillonites [100] & $0.025-0.3$ & 25 & 0.005 & $97-100$ & $96-100$ \\
\hline $\begin{array}{c}\text { Corynebacterium glutamicum MTCC } 2745 \\
\text { biofilm supported on Neem leaves } \\
\mathrm{NL} / \mathrm{MnFe}_{2} \mathrm{O}_{4} \text { composite [93] }\end{array}$ & $0.01-0.1$ & 100 & 50 & $79-82.5$ & $72-77$ \\
\hline $\begin{array}{l}\text { Bacillus arsenicus biofilms supported on a } \\
\text { Neem leaves } / \mathrm{MnFe}_{2} \mathrm{O}_{4} \text { composite [94] }\end{array}$ & $0.01-0.1$ & 100 & 50 & $86-89$ & $79-83$ \\
\hline M. charantia plants biomass [91] & $0.05-0.25$ & 50 & 0.5 & No data & $66-88$ \\
\hline Bone char [101] & $0.05-0.4$ & 500 & 0.5 & $30-100$ & No data \\
\hline
\end{tabular}




\subsection{Effects of Contact Time on As Adsorption}

The evaluation of operational parameters, such as the contact time (batch adsorption) and flow rate (column adsorption) are also important to determine the time at which the adsorption reaches equilibrium. The quantity of As adsorbed per unit mass of adsorbent, and the percentage of As adsorbed will be determined respectively using Equations (13) and (14) given below:

$$
\begin{gathered}
q_{t}=\left(\left(C_{0}-C_{t}\right) / M\right) \times V \\
A(\%)=\left(\left(C_{0}-C_{t}\right) / C_{0}\right) \times 100
\end{gathered}
$$

where, $q_{t}$ is the quantity of As adsorbed at time $t ; A(\%)$ is the percentage of As adsorbed at time $t ; C_{0}$ is the initial As concentration; $C_{t}$ is the concentration of As in the aqueous phase at time $t ; V$ is the volume of the aqueous solution; and $M$ is the mass of natural As that will be used in the experiment [102]. The increase in the flow rate causes a decrease in the contact time between the adsorbent and As solution, which in turn lowers its removal efficiency. If the contact time is not long enough, the surface of the adsorbent will not be able to be charged enough, which will be a waste of the adsorbent. On the other side, if the contact time is longer than the equilibrium time, the adsorbent might start releasing back some As particles in the aqueous solution, which will not benefit the removal efficiency $[103,104]$. Frequently, the quantity of As adsorbed increases rapidly because there are still many adsorption sites on the natural adsorbent surface at first, then it will gradually slow down until it stays constant after the equilibrium adsorption time [105-109].

The augmentation of flow rate on As adsorption by thioglycolated sugarcane carbon (TSCC) and iron-modified cement slurry have been studied. The collected data showed that the As removal performance decreased with the increase in the flow rate from 3.0 to

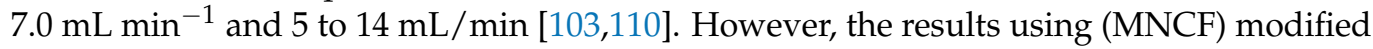
nonwoven cotton fabric, modified rice husk particles for As removal from water, showed that within $1 \mathrm{~h}$ a high As adsorption rate (almost 80\%) was noticed [55,111]. The marine sand might have fast As adsorption in comparison to algae, as zirconium oxide-coated marine sand (ZrOCMS) removed more than $90 \%$ within $75 \mathrm{~min}$, which is quick [112] compared to bio-adsorbents, such as algae (Lessonia nigrescens), in which the maximum adsorption capacity was reached after $300 \mathrm{~min}$ [113].

\section{3. $p H$}

The adsorption of As ions species are strongly governed by the $\mathrm{pH}$ of the aqueous solution. The $\mathrm{pH}$ of the solution is an important parameter, which controls the As species present in water and the natural adsorbent surface chemical composition [114]. The distributing equation of $\mathrm{As}(\mathrm{III})$ is as follows:

$$
\begin{gathered}
\mathrm{H}_{3} \mathrm{AsO}_{3}=\mathrm{H}^{+}+\mathrm{H}_{2} \mathrm{AsO}_{3}{ }^{-}, \mathrm{pKa}_{1}=9.2 \\
\mathrm{H}_{2} \mathrm{AsO}_{3}{ }^{-}=\mathrm{H}^{+}+\mathrm{HAsO}_{3}{ }^{2-}, \mathrm{pKa}_{2}=12.1 \\
\mathrm{HAsO}_{3}{ }^{2-}=\mathrm{H}^{+}+\mathrm{AsO}_{3}{ }^{3-}, \mathrm{pKa}_{3}=13.4
\end{gathered}
$$

The distributing equation of $\mathrm{As}(\mathrm{V})$ is as follows:

$$
\begin{aligned}
& \mathrm{H}_{3} \mathrm{AsO}_{4}=\mathrm{H}^{+}+\mathrm{H}_{2} \mathrm{AsO}_{4}{ }^{-}, \mathrm{pKa}_{1}=2.1 \\
& \mathrm{H}_{2} \mathrm{AsO}_{4}{ }^{-}=\mathrm{H}^{+}+\mathrm{HAsO}_{4}{ }^{2-}, \mathrm{pKa}_{2}=7 \\
& \mathrm{HAsO}_{4}{ }^{2-}=\mathrm{H}^{+}+\mathrm{AsO}_{4}{ }^{3-}, \mathrm{pKa}_{3}=11.2
\end{aligned}
$$

Mostly, if the As removal is through chemical adsorption, the As(III) adsorption is better at a high $\mathrm{pH}$ [115] because at $\mathrm{pH}$ 1-7 the predominant $\mathrm{As}$ (III) species $\mathrm{H}_{3} \mathrm{AsO}_{3}$ ( $\mathrm{pKa}=9.2)$ is uncharged, which can negatively impact the As removal performance. As shown in Figure 3, the adsorption performance of As(III) increased notably with the increase in the solution $\mathrm{pH}$, and the best solution $\mathrm{pH}$ for $\mathrm{As}(\mathrm{III})$ adsorption was around 
$\mathrm{pH}=8.5$ when the copper impregnated coconut husk carbon (CICHC) was used as the adsorbent [116]. A study using fly ash from the power plant after burning biomass and coal for As(III) removal showed that the best removal data was around $\mathrm{pH} 12$ [117]. However, for $\mathrm{As}(\mathrm{V})$, its removal is mostly better at a low $\mathrm{pH}$ because the adsorption performance decreases with the diminution of $\mathrm{H}_{2} \mathrm{AsO}_{4}{ }^{-}(\mathrm{pKa}=7)$ percentage in the aqueous solution [81,118-122]. As it can be seen in the Figure 4, Wang et al. [123], using $\mathrm{Ni} / \mathrm{Fe}$ modified loblolly pine (Pinus taeda) wood biochar (NFMB) for As(V) removal, showed that the adsorption capacity decreased with the solution $\mathrm{pH}$ rising from 3 to 9 . Another study using iron-modified loblolly pine (Pinus taeda) wood biochar (nZVI/BC) for $\mathrm{As}(\mathrm{V})$ removal showed that the removal efficiency decreased briskly at $\mathrm{pHs} 3-3.7$, and kept dropping as the solution $\mathrm{pH}$ increased [124].

\subsection{Reusability}

Desorption and regeneration are important parameters because a good natural adsorbent is an adsorbent that can remove enough As from water and can be reused without losing its adsorption performance too much, which indicates that the adsorbent can be recycled and reused. The loss of the adsorption capacity, after much desorption and regeneration, is due to the loss of adsorption sites on the adsorbent surface $[90,123,125,126]$. Generally, it can be noticed in the Table 3, most of the natural adsorbents have good reuse performance. It was determined that after the iron hydroxide/manganese dioxide doped straw activated carbon (Fe-Mn-Sac) was used for three adsorption-desorption cycles, the adsorption capacity of Fe-Mn-Sac had a negligible variation (from $85 \%$ to $78 \%$ ) [127]. For iron-modified water hyacinth biochar, the arsenate removal percentage decreased from 100 to $65 \%$ after four cycles of regeneration, which was not a bad performance regarding the high arsenate initial concentration in the water $(5 \mathrm{mg} / \mathrm{L})$ [128].

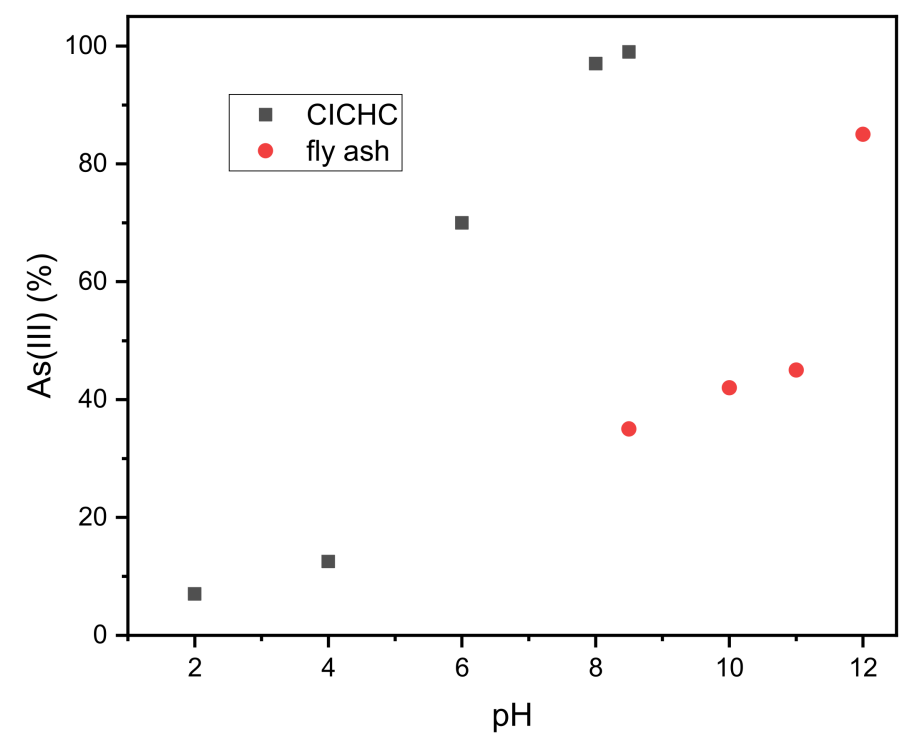

Figure 3. As(III) adsorption as a function of $\mathrm{pH}$ variation $[116,117]$. 


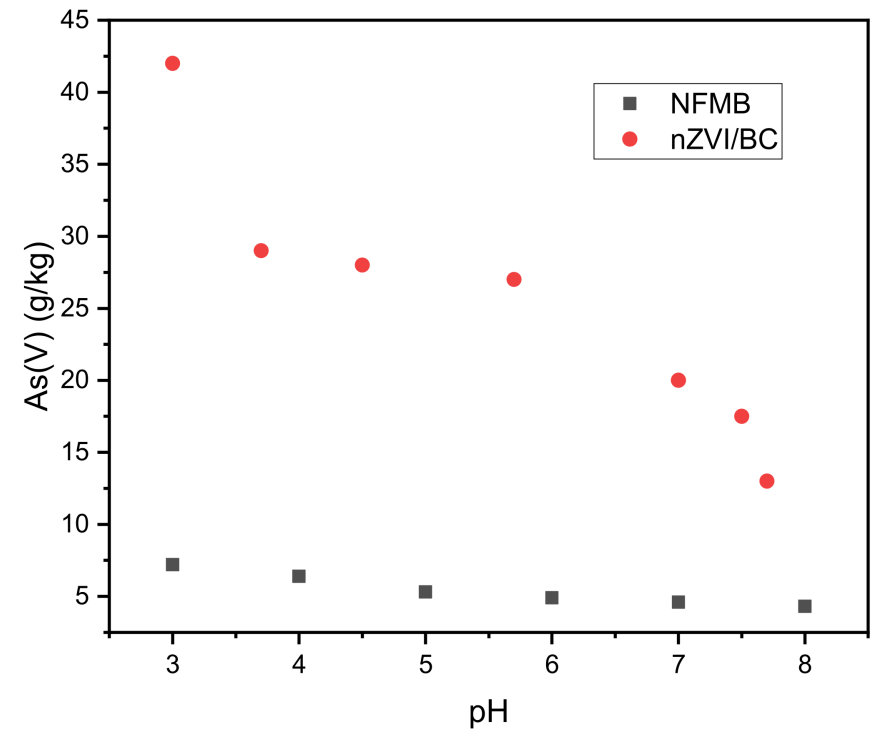

Figure 4. As(V) adsorption as a function of $\mathrm{pH}$ variation $[123,124]$.

Table 3. Studies on some natural adsorbent's reusability performance.

\begin{tabular}{|c|c|c|c|c|c|c|}
\hline \multirow{2}{*}{ Adsorbent } & \multirow{2}{*}{$\begin{array}{l}\text { Adsorbent } \\
\text { Dosage (g) }\end{array}$} & \multirow{2}{*}{$\begin{array}{c}\text { Intial } \\
\text { Concentration } \\
(\mathrm{mg} / \mathrm{L})\end{array}$} & \multirow{2}{*}{ Regenetaion } & \multicolumn{2}{|c|}{ Adsorption Capacity (\%) } & \multirow{2}{*}{ Reference } \\
\hline & & & & $\operatorname{As}(\mathrm{V})$ & As(III) & \\
\hline $\begin{array}{c}\text { The green alga } \\
\text { (U. cylindricum) biomass [129] }\end{array}$ & 0.1 & 10 & 10 & No data & $96-93$ & $\begin{array}{l}\text { Tuzen M. } \\
\text { et al., } 2009\end{array}$ \\
\hline $\begin{array}{l}\text { Ni/Mn-layered double } \\
\text { hydroxide (LDH) biochar } \\
\text { (NMMB) [123] }\end{array}$ & 0.1 & 40 & 3 & 100-98 & No data & $\begin{array}{l}\text { Wang S. S. } \\
\text { et al., 2016a }\end{array}$ \\
\hline $\begin{array}{c}\mathrm{Ni} / \mathrm{Fe} \text { layered double } \\
\text { hydroxide (LDH)-biochar } \\
\text { (NFMB) [130] }\end{array}$ & 0.1 & 50 & 3 & 100-92 & No data & $\begin{array}{l}\text { Wang S. S. } \\
\text { et al., 2016b }\end{array}$ \\
\hline $\begin{array}{l}\text { Charred orange peel } \\
\text { (COP) [131] }\end{array}$ & 0.2 & 200 & 3 & $100-90$ & No data & $\begin{array}{l}\text { Abid M. et al., } \\
2016\end{array}$ \\
\hline Fe-Mn-straw biochars [127] & 1 & 20 & 3 & No data & $85-78$ & $\begin{array}{l}\text { Xiong Y. et al., } \\
2017\end{array}$ \\
\hline $\begin{array}{c}\text { Xanthated water melon rind } \\
\text { (X-WMR) [132] }\end{array}$ & 0.2 & $\begin{array}{c}\mathrm{As}(\mathrm{III}) \\
4\end{array}$ & 4 & $100-50$ & 100-20 & $\begin{array}{l}\text { Shakoor M. B. } \\
\text { et al., } 2018\end{array}$ \\
\hline $\begin{array}{c}\text { Magnetite-modified water } \\
\text { hyacinth } \\
\text { Biochar }\left(\mathrm{MW} 250_{1}\right)[128]\end{array}$ & 0.2 & 5 & 4 & $100-50$ & No data & $\begin{array}{l}\text { Zhang F. et al., } \\
2016\end{array}$ \\
\hline $\begin{array}{l}\text { 20\% Iron-impregnated corn } \\
\text { straw biochar [125] }\end{array}$ & 0.2 & 40 & 3 & $87-70$ & No data & $\begin{array}{l}\text { He R. Z. et al., } \\
2018\end{array}$ \\
\hline $\begin{array}{l}\text { Modified Saccharum } \\
\text { officinarum bagasse } \\
\text { (SCB-S) [133] }\end{array}$ & 0.05 & 0.5 & 5 & $100-78$ & $100-86$ & $\begin{array}{l}\text { Gupta A. } \\
\text { et al., } 2015\end{array}$ \\
\hline
\end{tabular}

\subsection{Thermodynamic}

The variation in temperature can have positive or negative impacts on the adsorbent's adsorption capacity $[134,135]$. Usually, for the adsorption thermodynamic study, Gibbs free energy $\left(\Delta G^{\circ}\right)$, entropy $\left(\Delta S^{\circ}\right)$, and enthalpy $\left(\Delta H^{\circ}\right)$ of the adsorption are calculated using van't Hoff thermo-dynamic equations:

$$
\begin{gathered}
\Delta G^{\circ}=-R T \ln \left(K_{D}\right) \\
\ln \left(K_{D}\right)=\Delta S^{\circ} / R-\Delta H^{\circ} /(R T)
\end{gathered}
$$


where $R$ is the universal gas constant $(8.314 \mathrm{~J} / \mathrm{mol} \mathrm{K}), T$ is temperature $(K)$, and $K_{D}\left(q_{e} / C_{e}\right)$ is the distribution coefficient. According to Equation (22), the entropy $\left(\Delta S^{\circ}\right)$ and enthalpy $\left(\Delta H^{\circ}\right)$ of the adsorption parameters can be determined from the slope and intercept of the plot of $\ln \left(K_{D}\right)$ vs. $1 / T$ yields, respectively, and then used to calculate the Gibbs free energy $\left(\Delta G^{\circ}\right)[129]$.

The term physical sorption means a van der Waals type force formed between the interfaces and chemisorption, which denotes a chemical bond formed between the As molecule and the natural adsorbent surface. Generally, the physical sorption enthalpy $\left(\Delta H^{\circ}\right)$ is in the range of -20 to $-40 \mathrm{~kJ} \mathrm{~mol}^{-1}$ and chemisorption enthalpy $\left(\Delta H^{\circ}\right)$ in the range of -400 to $-80 \mathrm{~kJ} \mathrm{~mol}^{-1}[136,137]$. Usually, the adsorption of As on natural adsorbents are spontaneous chemisorption processes [133]. Take chemically modified watermelon rind for example, the negative values of $\Delta G^{\circ}$ suggested that both $\mathrm{As}(\mathrm{III})$ and $\mathrm{As}(\mathrm{V})$ adsorption was spontaneous; the positive values of $\Delta H^{\circ}$ for both $\mathrm{As}(\mathrm{III})\left(67 \mathrm{~kJ} \mathrm{~mol}^{-1}\right)$ and As(V) $\left(86.05 \mathrm{~kJ} \mathrm{~mol}^{-1}\right)$ sorption indicated that sorption was endothermic; the positive $\Delta S^{\circ}$ values for both $\mathrm{As}(\mathrm{III})\left(0.24 \mathrm{~kJ} \mathrm{~mol}^{-1}\right)$ and $\mathrm{As}(\mathrm{V})\left(0.58 \mathrm{~kJ} \mathrm{~mol}^{-1}\right)$ suggested a disorder at the solid/solution interface along with structural changes [132].

\subsection{Influence of Other Ions}

Many common ions which can be present in water, especially groundwater, can negatively impact the removal of As due to the capacity of these ions to compete with As for adsorption [138]. In general, as shown in the Table 4, the adsorption capacity of As onto a natural adsorbent in the presence of positive anions $\left(\mathrm{Mg}^{2+}, \mathrm{Ca}^{2+}, \mathrm{Mn}^{2+}\right)$ is higher than in the presence of negative anions $\left(\mathrm{NO}_{3}{ }^{-}, \mathrm{SO}_{4}{ }^{2-}, \mathrm{PO}_{4}{ }^{3-}\right)$ because of the electrostatic competition between the negative other anions and the As anions for the adsorption onto the natural adsorbent surface, and the repulsion between the positively charged natural adsorbent surface and the positive anions $[89,139,140]$. Minerals might have better selectivity compared to biomass, for example, leonardite was used for As removal and the results showed that the enhanced $\mathrm{SO}_{4}{ }^{2-}$ concentration in the solution led to the reduction in As removal capacity from 100 to 95\% [141], while Baig et al. [135] found that the removal efficiency of As(III) on the iron modified Kans grass (Saccharum spontaneum) biochar dropped notably below $20 \%$, when the concentration of $\mathrm{PO}_{4}{ }^{3-}$ increased to $1.0 \mathrm{mmol} / \mathrm{L}$.

Table 4. Other ions influence on some natural adsorbents.

\begin{tabular}{|c|c|c|c|c|c|c|}
\hline \multirow{2}{*}{ Adsorbents } & \multirow{2}{*}{ Thermodynamics } & \multirow{2}{*}{ Kenetic } & \multirow{2}{*}{\multicolumn{2}{|c|}{ Influence Ions (mg/L) }} & \multicolumn{2}{|c|}{ Removal As (\%) } \\
\hline & & & & & As(III) & $\operatorname{As}(V)$ \\
\hline \multirow{2}{*}{$\begin{array}{l}\text { Acid-activated laterite } \\
\text { (AAL) [134] }\end{array}$} & \multirow{2}{*}{ Endothermic } & \multirow{2}{*}{$\begin{array}{l}\text { Pseudo-second- } \\
\text { order }\end{array}$} & $\mathrm{PO}_{4}{ }^{3-}$ & $0-10$ & $89-70$ & $95-85$ \\
\hline & & & $\mathrm{SO}_{4}^{2-}$ & $0-40$ & $89-68$ & $95-83$ \\
\hline $\begin{array}{c}\mathrm{Fe}_{3} \mathrm{O}_{4}-\mathrm{HBC}-1000{ }^{\circ} \mathrm{C} \\
\text { (Honeycomb Briquette } \\
\text { Cinders) [142] }\end{array}$ & Endothermic & $\begin{array}{l}\text { Pseudo-second- } \\
\text { order }\end{array}$ & $\mathrm{PO}_{4}{ }^{3-}$ & $0-9.5$ & $100-15$ & $100-60$ \\
\hline $\begin{array}{l}\text { Fe-Mn modified corn stem } \\
\text { biochar (FMBC) [143] }\end{array}$ & Endothermic & $\begin{array}{l}\text { Pseudo-second- } \\
\text { order }\end{array}$ & $\mathrm{PO}_{4}{ }^{3-}$ & 0-9500 & $100-88$ & No data \\
\hline $\begin{array}{l}\text { Iron oxide amended rice } \\
\text { husk char } \\
\text { (950 IOA-RHC) [138] }\end{array}$ & Endothermic & $\begin{array}{l}\text { Pseudo-second- } \\
\text { order }\end{array}$ & $\mathrm{PO}_{4}{ }^{3-}$ & $0-10$ & No data & $100-65$ \\
\hline $\begin{array}{l}\text { Fe-impregnated hickory } \\
\text { chips biochar [144] }\end{array}$ & No data & No data & $\mathrm{PO}_{4}^{3-}$ & $0-50$ & No data & $100-15$ \\
\hline $\begin{array}{c}\text { Magnetic Kans Grass } \\
\text { (Saccharum spontaneum) } \\
\text { Biochars (MKGB4) [135] }\end{array}$ & No data & $\begin{array}{l}\text { Pseudo-second- } \\
\text { order }\end{array}$ & $\mathrm{PO}_{4}^{3-}$ & 0-95 & 100-20 & $100-80$ \\
\hline Leonardite chars [141] & No data & No data & $\mathrm{SO}_{4}{ }^{2-}$ & $0-5000$ & $98-92$ & $99-94$ \\
\hline Siderite SIO3 [145] & No data & No data & $\mathrm{PO}_{4}{ }^{3-}$ & $0-10$ & No data & $64-28$ \\
\hline Hematite HIO1 [145] & No data & First-order & $\mathrm{PO}_{4}{ }^{3-}$ & $0-10$ & No data & $69-36$ \\
\hline
\end{tabular}




\subsection{Adsorption Isotherm and Kinetic Model}

In the order to design an As removal system on a real scale, studies of adsorption isotherm and kinetics equation models are important to describe the nature of adsorption onto the natural adsorbents, and determine the adsorption capacity of As [146-149]. Many isotherm equation models exist, but the most use ones in the studies of As adsorption are the Langmuir Equation (23) and Freundlich Equation (24) linear equation.

$$
C_{e} / q_{e}=C_{e} / q_{m}+1 / q_{m} K_{a}
$$

where $C_{e}$ is the equilibrium concentration, $q_{e}$ is the equilibrium adsorption capacity of As onto adsorbent, $q_{m}$ is the maximum adsorption capacity, and $K_{a}$ is the Langmuir sorption equilibrium constant [150].

$$
\log q_{e}=1 / n \times \log C_{e}+\log K_{f}
$$

where $C_{e}$ and $q_{e}$ have the same meaning as explained above, $K_{f}$ and $n$ are the Freundlich isotherm constants, representing the adsorption capacity and intensity, respectively [151].

The Langmuir model is an equation which is used to describe monolayer adsorption onto a homogeneous surface. The Freundlich model assumes chemisorption on heterogeneous surface [152,153]. As we can see in Table 1, the Langmuir model is the isotherm sorption model that most of the time explains the adsorption mechanism when a natural adsorbent is used.

There are two kinetics models that are mostly used, which are the pseudo-first-order model (Equation (25) [154] and pseudo-second-order model (Equation (26) [155].

$$
\log \left(Q_{e}-Q_{t}\right)=\log Q_{e}-k_{1} / 2.303 t
$$

where $Q_{e}$ is the amount of As adsorbed on the surface of the adsorbent at equilibrium $(\mu \mathrm{g} / \mathrm{g}), Q_{t}$ is amount of As on the surface of the adsorbent at time any $t(\mu \mathrm{g} / \mathrm{g})$, and $k_{1}$ is the equilibrium rate constant of pseudo-first-order sorption $(\mathrm{L} / \mathrm{min})$. The rate constants are calculated by plotting $\log \left(Q_{e}-Q_{t}\right)$ vs. $t$.

$$
t / Q_{t}=1 / k_{2} Q_{e}{ }^{2}+t / Q_{e}
$$

where $t, Q_{t}$, and $Q_{e}$ have the same meaning as explained above. $k_{2}$ is the rate constant of pseudo-second-order adsorption $\left(\mathrm{g} \cdot \mu \mathrm{g}^{-1} \cdot \mathrm{min}^{-1}\right)$. The rate constants are calculated by plotting $t / Q_{t}$ vs. $t$.

The pseudo-second-order kinetic model assumes that chemisorption is the main adsorption mechanism [156] and the pseudo-first-order kinetic model indicates that physical sorption is the adsorption mechanism [140]. Mostly, as we can see in Table 4, when a biomaterial, such as the iron-modified chitosan hollow fibers membrane, $\mathrm{ZnCl}_{2}$-activated pig manure residue biochar, pine bark, pine wood, oak bark, and oak wood biochar is used for $\mathrm{As}(\mathrm{III})$ or $\mathrm{As}(\mathrm{V})$ removal, the principal adsorption mechanism is a chemisorption [157-159].

\section{Conclusions}

Some biosorbents, such as fruit peels (orange, citrus, mango) and minerals (geothite) have a very nice As removal performance, but some others such as biomass or fibers (cotton, sugarcane, coconut) first need a pre-treatment to enhance their performance. As removal by natural adsorbent was found to be mainly endothermic and a spontaneous monolayer chemisorption, and depended on many different parameters; high As initial concentration may reduce the biosorbent As removal effectiveness, but more contact time can help to uptake more As from the water. Enough dosage of the natural sorbent and suitable water flow are very useful for better As removal performance, the adsorption of $\mathrm{As}(\mathrm{V})$ is suitable in acidic solution and $\mathrm{As}(\mathrm{III})$ is appropriate in a basic solution. The economic factor is the main reason why it will be better to use as natural adsorbent of As from water, a natural material which has no use in our society and usually becomes waste 
materials, such as sugar cane fibers, corn fibers, corn cane fibers, groundnut shell. The low cost, good adsorption, and desorption of the biosorbent prove that natural adsorbents are a good As adsorbent, which can help to set up an effective technology for any kind of water polluted by As. In the future, all these advantages of the natural sorbents for As removal from water should be presented to researchers, to increase the research using biosorbents for further As adsorption technology development. Comparisons of the natural sorbent As adsorption capacity with or without modification should be made to reduce the use of chemical products in the process. Moreover, more studies should be conducted using real polluted natural water to check the performance of natural sorbent in real conditions, especially using the column process.

Author Contributions: Conceptualization, K.F.H.Y.; Formal analysis, K.F.H.Y.; Investigation, K.F.H.Y.; Writing—original draft, K.F.H.Y.; Methodology, K.F.H.Y.; Writing-review \& editing, W.W.; Resources, W.W.; Supervision, W.W.; validation, C.L., H.Z., J.C., W.W. and Y.D. All authors have read and agreed to the published version of the manuscript.

Funding: Funded by Technology Innovation Center for Land Engineering and Human Settlements; Shaanxi Land Engineering Construction Group Co., Ltd.; Xi'an Jiaotong University (No. 201912131) and Science technology Project of Yulin (No. YF-2020-007).

Institutional Review Board Statement: Not applicable.

Informed Consent Statement: Not applicable.

Data Availability Statement: Data sharing is not applicable to this article.

Conflicts of Interest: The authors declare no conflict of interest.

\section{References}

1. Jain, C.; Ali, P.I. Arsenic: Occurrence, Toxicity and Speciation Techniques. Water Res. 2000, 34, 4304-4312. [CrossRef]

2. Smedley, P.L.; Kinniburgh, D.G. A review of the source, behaviour and distribution of arsenic in natural waters. Appl. Geochem. 2002, 17, 517-568. [CrossRef]

3. Mandal, B.K.; Suzuki, K.T. Arsenic round the world: A review. Talanta 2002, 58, 201-235. [CrossRef]

4. Mohan, D.; Pittman, C.U., Jr. Arsenic removal from water/wastewater using adsorbents—A critical review. J. Hazard. Mater. 2007, 142, 1-53. [CrossRef]

5. Naidu, R.; Smith, E.; Owens, G.; Bhattacharya, P.; Nadebaum, P.; Collingwood, V. Managing Arsenic in the Environment from Soil to Human Health; CSIRO Publishing: Clayton, Australia, 2006.

6. Shakoor, M.B.; Niazi, N.K.; Bibi, I.; Rahman, M.M.; Naidu, R.; Dong, Z.; Shahid, M.; Arshad, M. Unraveling Health Risk and Speciation of Arsenic from Groundwater in Rural Areas of Punjab, Pakistan. Int. J. Environ. Res. Public Health 2015, 12, 12371-12390. [CrossRef]

7. Cutter, G. Kinetic controls on metalloid speciation in seawater. Mar. Chem. 1992, 40, 65-80. [CrossRef]

8. Van Genuchten, C.M.; Ahmad, A. Groundwater As Removal by As(III), Fe(II), and Mn(II) Co-Oxidation: Contrasting As Removal Pathways with $\mathrm{O}_{2}, \mathrm{NaOCl}$, and $\mathrm{KMnO}_{4}$. Environ. Sci. Technol. 2020, 54, 15454-15464. [CrossRef]

9. Gecol, H.; Ergican, E.; Fuchs, A. Molecular level separation of arsenic (V) from water using cationic surfactant micelles and ultrafiltration membrane. J. Membr. Sci. 2004, 241, 105-119. [CrossRef]

10. National Research Council USA. Arsenic in Drinking Water: 2001 Update; NRC: Washington, DC, USA, 2001.

11. Mazumder, D.N.G. Chronic Arsenic Toxicity: Clinical Features, Epidemiology, and Treatment: Experience in West Bengal. J. Environ. Sci. Health Part A 2003, 38, 141-163. [CrossRef]

12. Babel, S.; Kurniawan, T. Low-Cost Adsorbents for Heavy Metals Uptake from Contaminated Water: A Review. J. Hazard. Mater. 2003, 97, 219-243. [CrossRef]

13. Raul, P.; Devi, R.R.; Umlong, I.M.; Banerjee, S.; Singh, L.; Purkait, M.K. Removal of Fluoride from Water Using Iron OxideHydroxide Nanoparticles. J. Nanosci. Nanotechnol. 2012, 12, 3922-3930. [CrossRef]

14. Daus, B.; Wennrich, R.; Weiss, H. Sorption materials for arsenic removal from water: A comparative study. Water Res. 2004, 38, 2948-2954. [CrossRef]

15. Yin, H.; Liu, F.; Feng, X.; Liu, M.; Tan, W.; Qiu, G. Co ${ }^{2+}$-exchange mechanism of birnessite and its application for the removal of $\mathrm{Pb}^{2+}$ and As(III). J. Hazard. Mater. 2011, 196, 318-326. [CrossRef]

16. Wang, J.; Zhou, X.F.; Ma, J.X. Preparation and Characteristics of a Paper-Based Ultrafiltration Membrane. Bioresources 2012, 7, 545-553.

17. Nguyen, V.T.; Vigneswaran, S.; Ngo, H.H.; Shon, H.K.; Kandasamy, J. Arsenic removal by a membrane hybrid filtration system. Desalination 2009, 236, 363-369. [CrossRef] 
18. Yang, Z.; Zhou, Y.; Feng, Z.; Rui, X.; Zhang, T.; Zhang, Z. A Review on Reverse Osmosis and Nanofiltration Membranes for Water Purification. Polymers 2019, 11, 1252. [CrossRef]

19. Pallier, V.; Feuillade-Cathalifaud, G.; Serpaud, B.; Bollinger, J.-C. Effect of organic matter on arsenic removal during coagulation/flocculation treatment. J. Colloid Interface Sci. 2010, 342, 26-32. [CrossRef]

20. Meharg, A.A.; Whitaker, J. Arsenic uptake and metabolism in arsenic resistant and nonresistant plant species. New Phytol. 2002, 154, 29-43. [CrossRef]

21. Zhitomirsky, I. Cathodic electrodeposition of ceramic and organoceramic materials. Fundamental aspects. Adv. Colloid Interface Sci. 2002, 97, 279-317. [CrossRef]

22. Mollah, M.A.; Schennach, R.; Parga, J.R.; Cocke, D.L. Electrocoagulation (EC)—Science and applications. J. Hazard. Mater. 2001, 84, 29-41. [CrossRef]

23. Mollah, M.Y.; Morkovsky, P.; Gomes, J.A.; Kesmez, M.; Parga, J.; Cocke, D.L. Fundamentals, present and future perspectives of electrocoagulation. J. Hazard. Mater. 2004, 114, 199-210. [CrossRef]

24. Tanaka, Y. Water dissociation in ion-exchange membrane electrodialysis. J. Membr. Sci. 2002, 203, 227-244. [CrossRef]

25. Casqueira, R.; Torem, M.; Kohler, H. The removal of zinc from liquid streams by electroflotation. Miner. Eng. 2006, 19, 1388-1392. [CrossRef]

26. Pyo, M.; Moon, I. Indirect Electrochemical Oxidation of Phenol by $\mathrm{Ce}^{4+}$, Controlling Surface Insulation of Au Electrode. Bull. Korean Chem. Soc. 2005, 26, 899-902.

27. Chua, H. Bio-accumulation of environmental residues of rare earth elements in aquatic flora Eichhornia crassipes (Mart.) Solms in Guangdong Province of China. Sci. Total Environ. 1998, 214, 79-85. [CrossRef]

28. Maine, M.A.; Duarte, M.V.; Suñé, N.L. Cadmium uptake by floating macrophytes. Water Res. 2001, 35, 2629-2634. [CrossRef]

29. Ghurye, G.L.; Clifford, D.A.; Tripp, A.R. Combined arsenic and nitrate removal by ion exchange. J. Am. Water Work. Assoc. 1999, 91, 85-96. [CrossRef]

30. Seifert, W.; Liu, X.; Samuelson, L. Influence of arsenic adsorption layers on heterointerfaces in GaInAs/InP quantum well structures. Appl. Phys. Lett. 1993, 62, 949-951. [CrossRef]

31. Hering, J.G.; Chen, P.-Y.; Wilkie, J.A.; Elimelech, M.; Liang, S. Arsenic removal by ferric chloride. J. Am. Water Work. Assoc. 1996, 88, 155-167. [CrossRef]

32. Lorenzen, L.; van Deventer, J.; Landi, W. Factors affecting the mechanism of the adsorption of arsenic species on activated carbon. Miner. Eng. 1995, 8, 557-569. [CrossRef]

33. Ghurye, G.; Clifford, D.; Tripp, A. Iron coagulation and direct microfiltration to remove arsenic from groundwater. J. Am. Water Work. Assoc. 2004, 96, 143-152. [CrossRef]

34. Xiong, T.-T.; Leveque, T.; Austruy, A.; Goix, S.; Schreck, E.; Dappe, V.; Sobanska, S.; Foucault, Y.; Dumat, C. Foliar uptake and metal(loid) bioaccessibility in vegetables exposed to particulate matter. Environ. Geochem. Health 2014, 36, 897-909. [CrossRef] [PubMed]

35. Igwe, J.C.; Abia, A.A.; Okenwa, S.I.; Gbaruko, B.C.; Nwokennaya, E.C. Detoxification of $\mathrm{Hg}^{2+}, \mathrm{As}^{3+}$ and $\mathrm{Pb}^{2+}$ metal ions from wastewater by biosorption using modified and unmodified coconut fiber: $\mathrm{pH}$, temperature and particle size effects. Am. Chem. Soc. 2005, 230, U1878-U1879.

36. Marín-Rangel, V.M.; Cortés-Martínez, R.; Villanueva, R.A.C.; Garnica-Romo, M.G.; Martínez-Flores, H.E. As (V) Biosorption in an Aqueous Solution Using Chemically Treated Lemon (Citrus aurantifolia Swingle) Residues. J. Food Sci. 2012, 77, T10-T14. [CrossRef] [PubMed]

37. Maiti, A.; DasGupta, S.; Basu, J.K.; De, S. Batch and Column Study: Adsorption of Arsenate Using Untreated Laterite as Adsorbent. Ind. Eng. Chem. Res. 2008, 47, 1620-1629. [CrossRef]

38. Yazdani, M.R.; Tuutijärvi, T.; Bhatnagar, A.; Vahala, R. Adsorptive removal of arsenic(V) from aqueous phase by feldspars: Kinetics, mechanism, and thermodynamic aspects of adsorption. J. Mol. Liq. 2016, 214, 149-156. [CrossRef]

39. Garg, U.; Kaur, M.; Jawa, G.; Sud, D.; Garg, V. Removal of cadmium (II) from aqueous solutions by adsorption on agricultural waste biomass. J. Hazard. Mater. 2008, 154, 1149-1157. [CrossRef]

40. Bailey, S.E.; Olin, T.J.; Bricka, R.; Adrian, D. A review of potentially low-cost sorbents for heavy metals. Water Res. 1999, 33, 2469-2479. [CrossRef]

41. Hashem, A.; Abdel-Halim, E.S.; El-Tahlawy, K.F.; Hebeish, A. Enhancement of the Adsorption of Co(II) and Ni(II) Ions onto Peanut Hulls through Esterification Using Citric Acid. Adsorpt. Sci. Technol. 2005, 23, 367-380. [CrossRef]

42. Zewail, T.M.; El-Garf, S.A.M. Preparation of agriculture residue based adsorbents for heavy metal removal. Desalin. Water Treat. 2010, 22, 363-370. [CrossRef]

43. Ebrahimi, R.; Maleki, A.; Shahmoradi, B.; Daraei, H.; Mahvi, A.H.; Barati, A.H.; Eslami, A. Elimination of arsenic contamination from water using chemically modified wheat straw. Desalin. Water Treat. 2013, 51, 2306-2316. [CrossRef]

44. Tian, Y.; Wu, M.; Lin, X.; Huang, P.; Huang, Y. Synthesis of magnetic wheat straw for arsenic adsorption. J. Hazard. Mater. 2011, 193, 10-16. [CrossRef]

45. Cheraghi, M.; Lorestani, B.; Merrikhpour, H.; Mosaed, H.P. Assessment efficiency of tea wastes in arsenic removal from aqueous solution. Desalin. Water Treat. 2013, 52, 7235-7240. [CrossRef]

46. Kamala, C.; Chu, K.; Chary, N.; Pandey, P.K.; Ramesh, S.; Sastry, A.; Sekhar, K. Removal of arsenic(III) from aqueous solutions using fresh and immobilized plant biomass. Water Res. 2005, 39, 2815-2826. [CrossRef] 
47. Nashine, A.; Tembhurkar, A. Equilibrium, kinetic and thermodynamic studies for adsorption of As(III) on coconut (Cocos nucifera L.) fiber. J. Environ. Chem. Eng. 2016, 4, 3267-3273. [CrossRef]

48. Nashine, A.; Tembhurkar, A. Iron oxide impregnated sugarcane bagasse waste material as sorbent for As(III) removal from water: Kinetic, equilibrium and thermodynamic studies. J. Water Supply Res. Technol. 2016, 65, 645-652. [CrossRef]

49. Urik, M.; Littera, P.; Kolen, M. Removal of arsenic (V) from aqueous solutions using chemically modified sawdust of spruce (Picea abies): Kinetics and isotherm studies. Int. J. Environ. Sci. Technol. 2009, 6, 451-456. [CrossRef]

50. Khaskheli, M.I.; Memon, S.Q.; Siyal, A.N.; Khuhawar, M.Y. Use of Orange Peel Waste for Arsenic Remediation of Drinking Water. Waste Biomass-Valoriz. 2011, 2, 423-433. [CrossRef]

51. Kumari, P.; Sharma, P.; Srivastava, S.; Srivastava, M. Biosorption studies on shelled Moringa oleifera Lamarck seed powder: Removal and recovery of arsenic from aqueous system. Int. J. Miner. Process. 2006, 78, 131-139. [CrossRef]

52. Kamsonlian, S.; Suresh, S.; Ramanaiah, V.; Majumder, C.B.; Chand, S.; Kumar, A. Biosorptive behaviour of mango leaf powder and rice husk for arsenic(III) from aqueous solutions. Int. J. Environ. Sci. Technol. 2012, 9, 565-578. [CrossRef]

53. Kamsonlian, S.; Suresh, S.; Majumder, C.; Chand, S. Biosorption of Arsenic by Mosambi (Citrus limetta) Peel: Equilibrium, Kinetics, Thermodynamics and Desorption Study. Asian J. Chem. 2013, 25, 2409-2417. [CrossRef]

54. Ouédraogo, I.W.K.; Pehlivan, E.; Tran, H.T.; Bonzi-Coulibaly, Y.L.; Zachmann, D.; Bahadir, M. Synthesis of iron oxyhydroxidecoated rice straw (IOC-RS) and its application in arsenic(V) removal from water. J. Water Health 2015, 13, 726-736. [CrossRef]

55. Pehlivan, E.; Tran, T.; Ouédraogo, W.; Schmidt, C.; Zachmann, D.; Bahadir, M. Removal of As(V) from aqueous solutions by iron coated rice husk. Fuel Process. Technol. 2013, 106, 511-517. [CrossRef]

56. Montero, J.I.Z.; Monteiro, A.S.; Gontijo, E.S.; Bueno, C.C.; de Moraes, M.A.; Rosa, A.H. High efficiency removal of As(III) from waters using a new and friendly adsorbent based on sugarcane bagasse and corncob husk Fe-coated biochars. Ecotoxicol. Environ. Saf. 2018, 162, 616-624. [CrossRef]

57. Anirudhan, T.; Unnithan, M.R. Arsenic(V) removal from aqueous solutions using an anion exchanger derived from coconut coir pith and its recovery. Chemosphere 2007, 66, 60-66. [CrossRef]

58. Haldhar, D.; Sahoo, S.; Mishra, P. Adsorption of As (III) From Aqueous Solution by Groundnut Shell. Indian J. Appl. Res. 2014, 4, $2249-2255$.

59. Guo, X.; Chen, F. Removal of Arsenic by Bead Cellulose Loaded with Iron Oxyhydroxide from Groundwater. Environ. Sci. Technol. 2005, 39, 6808-6818. [CrossRef]

60. Setyono, D.; Valiyayeettil, S. Chemically Modified Sawdust as Renewable Adsorbent for Arsenic Removal from Water. ACS Sustain. Chem. Eng. 2014, 2, 2722-2729. [CrossRef]

61. Pillai, P.; Kakadiya, N.; Timaniya, Z.; Dharaskar, S.; Sillanpaa, M. Removal of arsenic using iron oxide amended with rice husk nanoparticles from aqueous solution. Mater. Today Proc. 2020, 28, 830-835. [CrossRef]

62. Sarmah, S.; Saikia, J.; Phukan, A.; Goswamee, R.L. Adsorption of As(V) from Water over a Hydroxyl-Alumina Modified Paddy Husk Ash Surface and Its Sludge Immobilization. Water Air Soil Pollut. 2019, 230, 32. [CrossRef]

63. Nasseri, S.; Heidari, M. Evaluation and comparison of aluminum-coated pumice and zeolite in arsenic removal from water resources. Iran. J. Environ. Health Sci. Eng. 2012, 9, 38. [CrossRef] [PubMed]

64. Gupta, V.; Saini, V.; Jain, N. Adsorption of As(III) from aqueous solutions by iron oxide-coated sand. J. Colloid Interface Sci. 2005, 288, 55-60. [CrossRef] [PubMed]

65. Aredes, S.; Klein, B.; Pawlik, M. The removal of arsenic from water using natural iron oxide minerals. J. Clean. Prod. 2012, 29-30, 208-213. [CrossRef]

66. Jeon, C.-S.; Baek, K.; Park, J.-K.; Oh, Y.-K.; Lee, S.-D. Adsorption characteristics of As(V) on iron-coated zeolite. J. Hazard. Mater. 2009, 163, 804-808. [CrossRef]

67. Chen, W.; Parette, R.; Zou, J.; Cannon, F.S.; Dempsey, B.A. Arsenic removal by iron-modified activated carbon. Water Res. 2007, 41, 1851-1858. [CrossRef]

68. Khalid, N.; Ahmad, S.; Toheed, A.; Ahmed, J. Immobilization of Arsenic on Rice Husk. Adsorpt. Sci. Technol. 1998, 16, 655-666. [CrossRef]

69. Manning, B.A.; Goldberg, S. Modeling Competitive Adsorption of Arsenate with Phosphate and Molybdate on Oxide Minerals. Soil Sci. Soc. Am. J. 1996, 60, 121-131. [CrossRef]

70. Amin, M.N.; Kaneco, S.; Kitagawa, C.; Begum, A.; Katsumata, H.; Suzuki, T.; Ohta, K. Removal of arsenic in aqueous solutions by adsorption onto waste rice husk. Ind. Eng. Chem. Res. 2006, 45, 8105-8110. [CrossRef]

71. Doušová, B.; Fuitová, L.; Grygar, T.M.; Machovič, V.; Koloušek, D.; Herzogová, L.; Lhotka, M. Modified aluminosilicates as low-cost sorbents of As(III) from anoxic groundwater. J. Hazard. Mater. 2009, 165, 134-140. [CrossRef]

72. Luengo, C.; Puccia, V.; Avena, M. Arsenate adsorption and desorption kinetics on a Fe(III)-modified montmorillonite. J. Hazard. Mater. 2011, 186, 1713-1719. [CrossRef]

73. Katsoyiannis, I.A.; Zouboulis, A. Removal of arsenic from contaminated water sources by sorption onto iron-oxide-coated polymeric materials. Water Res. 2002, 36, 5141-5155. [CrossRef]

74. Poudel, B.R.; Aryal, R.L.; Bhattarai, S.; Koirala, A.R.; Gautam, S.K.; Ghimire, K.N.; Pant, B.; Park, M.; Paudyal, H.; Pokhrel, M.R. Agro-Waste Derived Biomass Impregnated with $\mathrm{TiO}_{2}$ as a Potential Adsorbent for Removal of As(III) from Water. Catalysts 2020, 10, 1125. [CrossRef] 
75. Sorg, T.J.; Wang, L.L. Arsenic removal from drunking water by activated alumina and anion exchange treatment. In Proceedings of the Small Drinking Water and Wastewater Systems, Phoenix, AZ, USA, 12 January 2000; pp. 282-291.

76. Maiti, A.; Dasgupta, S.; Basu, J.K.; De, S. Adsorption of arsenite using natural laterite as adsorbent. Sep. Purif. Technol. 2007, 55, 350-359. [CrossRef]

77. Twidwell, L.G.; Robins, R.G.; Hohn, J.W. The removal of arsenic from aqueous solution by coprecipitation with iron (III). In Proceedings of the Arsenic Metallurgy, Fundamentals and Applications, TMS Annual Meeting, San Francisco, CA, USA, 13-17 February 2005; pp. 3-24.

78. Roberts, L.C.; Hug, S.J.; Ruettimann, T.; Billah, M.; Khan, A.W.; Rahman, M.T. Arsenic Removal with Iron(II) and Iron(III) in Waters with High Silicate and Phosphate Concentrations. Environ. Sci. Technol. 2004, 38, 307-315. [CrossRef]

79. Maji, S.; Kao, Y.-H.; Liu, C.-W. Arsenic removal from real arsenic-bearing groundwater by adsorption on iron-oxide-coated natural rock (IOCNR). Desalination 2011, 280, 72-79. [CrossRef]

80. Joshi, A.; Chaudhuri, M. Removal of Arsenic from Ground Water by Iron Oxide-Coated Sand. J. Environ. Eng. 1996, 122, 769-771. [CrossRef]

81. Wu, K.; Liu, T.; Peng, J.M. Adsorption Behaviors of Arsenic(V) onto Fe-Based Backwashing Sludge Produced from Fe(II)-Removal Plants. Appl. Mech. Mater. 2013, 295-298, 1321-1326. [CrossRef]

82. Asif, Z.; Chen, Z. Removal of arsenic from drinking water using rice husk. Appl. Water Sci. 2017, 7, 1449-1458. [CrossRef]

83. Gupta, A.; Sankararamakrishnan, N. Column studies on the evaluation of novel spacer granules for the removal of arsenite and arsenate from contaminated water. Bioresour. Technol. 2010, 101, 2173-2179. [CrossRef]

84. Singh, T.S.; Pant, K. Experimental and modelling studies on fixed bed adsorption of As(III) ions from aqueous solution. Sep. Purif. Technol. 2006, 48, 288-296. [CrossRef]

85. Bhakat, P.; Gupta, A.; Ayoob, S. Feasibility analysis of As(III) removal in a continuous flow fixed bed system by modified calcined bauxite (MCB). J. Hazard. Mater. 2007, 139, 286-292. [CrossRef]

86. Deliyanni, E.A.; Bakoyannakis, D.N.; Zouboulis, A.; Peleka, E. Removal of Arsenic and Cadmium by Akaganeite Fixed-Beds. Sep. Sci. Technol. 2003, 38, 3967-3981. [CrossRef]

87. Wu, C.; Huang, L.; Xue, S.-G.; Huang, Y.-Y.; Hartley, W.; Cui, M.-Q.; Wong, M.H. Arsenic sorption by red mud-modified biochar produced from rice straw. Environ. Sci. Pollut. Res. 2017, 24, 18168-18178. [CrossRef] [PubMed]

88. Shafique, U.; Ijaz, A.; Salman, M.; Zaman, W.U.; Jamil, N.; Rehman, R.; Javaid, A. Removal of arsenic from water using pine leaves. J. Taiwan Inst. Chem. Eng. 2012, 43, 256-263. [CrossRef]

89. Liu, C.; Wang, B.; Deng, Y.; Cui, B.; Wang, J.; Chen, W.; He, S.-Y. Performance of a New Magnetic Chitosan Nanoparticle to Remove Arsenic and Its Separation from Water. J. Nanomater. 2015, 2015, 1-9. [CrossRef]

90. Wang, S.; Gao, B.; Li, Y.; Wan, Y.; Creamer, A.E. Sorption of arsenate onto magnetic iron-manganese (Fe-Mn) biochar composites. RSC Adv. 2015, 5, 67971-67978. [CrossRef]

91. Pandey, P.K.; Choubey, S.; Verma, Y.; Pandey, M.; Chandrashekhar, K. Biosorptive removal of arsenic from drinking water. Bioresour. Technol. 2009, 100, 634-637. [CrossRef]

92. Fan, T.; Liu, Y.; Feng, B.; Zeng, G.; Yang, C.; Zhou, M.; Zhou, H.; Tan, Z.; Wang, X. Biosorption of cadmium(II), zinc(II) and lead(II) by Penicillium simplicissimum: Isotherms, kinetics and thermodynamics. J. Hazard. Mater. 2008, 160, 655-661. [CrossRef]

93. Podder, M.; Majumder, C. Predictive approach for simultaneous biosorption and bioaccumulation of arsenic by Corynebacterium glutamicum MTCC 2745 biofilm supported on $\mathrm{NL} / \mathrm{MnFe}_{2} \mathrm{O}_{4}$ composite. J. Water Process. Eng. 2016, 11, 8-31. [CrossRef]

94. Podder, M.; Majumder, C. Study of the kinetics of arsenic removal from wastewater using Bacillus arsenicus biofilms supported on a Neem leaves $/ \mathrm{MnFe}_{2} \mathrm{O}_{4}$ composite. Ecol. Eng. 2016, 88, 195-216. [CrossRef]

95. Ansone-Bertina, L.; Klavins, M.; Viksna, A. Arsenic removal using natural biomaterial-based sorbents. Environ. Geochem. Health 2013, 35, 633-642. [CrossRef]

96. Ansone-Bertina, L.; Klavins, M.; Eglite, L. Use of peat-based sorbents for removal of arsenic compounds. Open Chem. 2013, 11, 988-1000. [CrossRef]

97. Verma, L.; Siddique, M.A.; Singh, J.; Bharagava, R.N. As(III) and As(V) removal by using iron impregnated biosorbents derived from waste biomass of Citrus limmeta (peel and pulp) from the aqueous solution and ground water. J. Environ. Manag. 2019, 250, 109452. [CrossRef]

98. Camacho, L.M.; Parra, R.R.; Deng, S. Arsenic removal from groundwater by $\mathrm{MnO}_{2}$-modified natural clinoptilolite zeolite: Effects of $\mathrm{pH}$ and initial feed concentration. J. Hazard. Mater. 2011, 189, 286-293. [CrossRef]

99. Wang, S.; Gao, B.; Zimmerman, A.; Li, Y.; Ma, L.; Harris, W.G.; Migliaccio, K. Removal of arsenic by magnetic biochar prepared from pinewood and natural hematite. Bioresour. Technol. 2015, 175, 391-395. [CrossRef]

100. Ren, X.; Zhang, Z.; Luo, H.; Hu, B.; Dang, Z.; Yang, C.; Li, L. Adsorption of arsenic on modified montmorillonite. Appl. Clay Sci. 2014, 97-98, 17-23. [CrossRef]

101. Chen, Y.-N.; Chai, L.-Y.; Shu, Y.-D. Study of arsenic(V) adsorption on bone char from aqueous solution. J. Hazard. Mater. 2008, 160, 168-172. [CrossRef]

102. Fufa, F.; Alemayehu, E.; Lennartz, B. Sorptive removal of arsenate using termite mound. J. Environ. Manag. 2014, 132, 188-196. [CrossRef]

103. Kundu, S.; Gupta, A. Analysis and modeling of fixed bed column operations on As(V) removal by adsorption onto iron oxide-coated cement (IOCC). J. Colloid Interface Sci. 2005, 290, 52-60. [CrossRef] 
104. Danish, M.I.; Qazi, I.A.; Zeb, A.; Habib, A.; Awan, M.A.; Khan, Z. Arsenic Removal from Aqueous Solution Using Pure and Metal-Doped Titania Nanoparticles Coated on Glass Beads: Adsorption and Column Studies. J. Nanomater. 2013, 2013, 1-17. [CrossRef]

105. Maji, S.K.; Pal, A.; Pal, T. Arsenic removal from aqueous solutions by adsorption on laterite soil. J. Environ. Sci. Health Part A 2007, 42, 453-462. [CrossRef] [PubMed]

106. Maji, S.K.; Pal, A.; Pal, T.; Adak, A. Sorption kinetics of arsenic on laterite soil in aqueous medium. J. Environ. Sci. Health Part A 2007, 42, 989-996. [CrossRef] [PubMed]

107. Kundu, S.; Kavalakatt, S.S.; Pal, A.; Ghosh, S.K.; Mandal, M.; Pal, T. Removal of arsenic using hardened paste of Portland cement: Batch adsorption and column study. Water Res. 2004, 38, 3780-3790. [CrossRef] [PubMed]

108. Altundoğan, H.S.; Altundoğan, S.; Tümen, F.; Bildik, M. Arsenic removal from aqueous solutions by adsorption on red mud. Waste Manag. 2000, 20, 761-767. [CrossRef]

109. Zhang, W.; Singh, P.; Paling, E.; Delides, S. Arsenic removal from contaminated water by natural iron ores. Miner. Eng. 2004, 17, 517-524. [CrossRef]

110. Roy, P.; Mondal, N.K.; Bhattacharya, S.; Das, B.; Das, K. Removal of arsenic(III) and arsenic(V) on chemically modified low-cost adsorbent: Batch and column operations. Appl. Water Sci. 2013, 3, 293-309. [CrossRef]

111. Korpayev, S.; Kavaklı, C.; Tilki, S.; Kavaklı, P.A. Novel cotton fabric adsorbent for efficient As(V) adsorption. Environ. Sci. Pollut. Res. 2018, 25, 34610-34622. [CrossRef]

112. Alam Khan, T.; Chaudhry, S.A.; Ali, I. Thermodynamic and kinetic studies of As(V) removal from water by zirconium oxide-coated marine sand. Environ. Sci. Pollut. Res. 2013, 20, 5425-5440. [CrossRef]

113. Hansen, H.K.; Ribeiro, A.; Mateus, E. Biosorption of arsenic(V) with Lessonia nigrescens. Miner. Eng. 2006, 19, 486-490. [CrossRef]

114. Raichur, A.; Panvekar, V. Removal of $\mathrm{As}(\mathrm{V})$ by adsorption onto mixed rare earth oxides. Sep. Sci. Technol. 2002, 37, 1095-1108. [CrossRef]

115. Dos Santos, H.H.; Demarchi, C.A.; Rodrigues, C.A.; Greneche, J.M.; Nedelko, N.; Slawska-Waniewska, A. Adsorption of As(III) on chitosan-Fe-crosslinked complex (Ch-Fe). Chemosphere 2011, 82, 278-283. [CrossRef]

116. Manju, G.N.; Raji, C.; Anirudhan, T.S. Evaluation of coconut husk carbon for the removal of arsenic from water. Water Res. 1998, 32, 3062-3070. [CrossRef]

117. Polowczyk, I.; Bastrzyk, A.; Ulatowska, J.; Szczałba, E.; Koźlecki, T.; Sadowski, Z. Influence of pH on arsenic(III) removal by fly ash. Sep. Sci. Technol. 2016, 51, 2612-2619. [CrossRef]

118. Giménez, J.; Martinez, M.; De Pablo, J.; Rovira, M.; Duro, L. Arsenic sorption onto natural hematite, magnetite, and goethite. J. Hazard. Mater. 2007, 141, 575-580. [CrossRef]

119. Ben Issa, N.; Rajaković-Ognjanović, V.N.; Marinković, A.; Rajaković, L.V. Separation and determination of arsenic species in water by selective exchange and hybrid resins. Anal. Chim. Acta 2011, 706, 191-198. [CrossRef]

120. Chuang, C.; Fan, M.; Xu, M.; Brown, R.; Sung, S.; Saha, B. Adsorption of arsenic(V) by activated carbon prepared from oat hulls. Chemosphere 2005, 61, 478-483. [CrossRef]

121. Swedlund, P.J.; Webster, J.G. Adsorption and polymerisation of silicic acid on ferrihydrite, and its effect on arsenic adsorption. Water Res. 1999, 33, 3413-3422. [CrossRef]

122. Niazi, N.K.; Bibi, I.; Shahid, M.; Ok, Y.S.; Burton, E.; Wang, H.; Shaheen, S.; Rinklebe, J.; Lüttge, A. Arsenic removal by perilla leaf biochar in aqueous solutions and groundwater: An integrated spectroscopic and microscopic examination. Environ. Pollut. 2018, 232, 31-41. [CrossRef]

123. Wang, S.; Gao, B.; Li, Y. Enhanced arsenic removal by biochar modified with nickel (Ni) and manganese (Mn) oxyhydroxides. J. Ind. Eng. Chem. 2016, 37, 361-365. [CrossRef]

124. Wang, S.; Gao, B.; Li, Y.; Creamer, A.E.; He, F. Adsorptive removal of arsenate from aqueous solutions by biochar supported zero-valent iron nanocomposite: Batch and continuous flow tests. J. Hazard. Mater. 2017, 322, 172-181. [CrossRef]

125. He, R.; Peng, Z.; Lyu, H.; Huang, H.; Nan, Q.; Tang, J. Synthesis and characterization of an iron-impregnated biochar for aqueous arsenic removal. Sci. Total Environ. 2018, 612, 1177-1186. [CrossRef]

126. Xu, Y.-H.; Nakajima, T.; Ohki, A. Adsorption and removal of arsenic(V) from drinking water by aluminum-loaded Shirasu-zeolite. J. Hazard. Mater. 2002, 92, 275-287. [CrossRef]

127. Xiong, Y.; Tong, Q.; Shan, W.; Xing, Z.; Wang, Y.; Wen, S.; Lou, Z. Arsenic transformation and adsorption by iron hydroxide/manganese dioxide doped straw activated carbon. Appl. Surf. Sci. 2017, 416, 618-627. [CrossRef]

128. Zhang, F.; Wang, X.; Xionghui, J.; Ma, L. Efficient arsenate removal by magnetite-modified water hyacinth biochar. Environ. Pollut. 2016, 216, 575-583. [CrossRef]

129. Tuzen, M.; Sari, A.; Mendil, D.; Uluozlu, O.D.; Soylak, M.; Dogan, M. Characterization of biosorption process of As(III) on green algae Ulothrix cylindricum. J. Hazard. Mater. 2009, 165, 566-572. [CrossRef]

130. Wang, S.; Gao, B.; Li, Y.; Zimmerman, A.R.; Cao, X. Sorption of arsenic onto Ni/Fe layered double hydroxide (LDH)-biochar composites. RSC Adv. 2016, 6, 17792-17799. [CrossRef]

131. Abid, M.; Niazi, N.K.; Bibi, I.; Farooqi, A.; Ok, Y.S.; Kunhikrishnan, A.; Ali, F.; Ali, S.; Igalavithana, A.D.; Arshad, M. Arsenic(V) biosorption by charred orange peel in aqueous environments. Int. J. Phytoremediat. 2016, 18, 442-449. [CrossRef] 
132. Shakoor, M.B.; Niazi, N.K.; Bibi, I.; Shahid, M.; Sharif, F.; Bashir, S.; Shaheen, S.M.; Wang, H.; Tsang, D.C.W.; Ok, Y.S.; et al. Arsenic removal by natural and chemically modified watermelon rind in aqueous solutions and groundwater. Sci. Total Environ. 2018, 645, 1444-1455. [CrossRef] [PubMed]

133. Gupta, A.; Vidyarthi, S.R.; Sankararamakrishnan, N. Concurrent removal of As(III) and As(V) using green low cost functionalized biosorbent-Saccharum officinarum bagasse. J. Environ. Chem. Eng. 2015, 3, 113-121. [CrossRef]

134. Maiti, A.; Basu, J.K.; De, S. Removal of arsenic from synthetic and natural groundwater using acid-activated laterite. Environ. Prog. Sustain. Energy 2010, 29, 457-470. [CrossRef]

135. Baig, S.A.; Zhu, J.; Muhammad, N.; Sheng, T.; Xu, X. Effect of synthesis methods on magnetic Kans grass biochar for enhanced As(III, V) adsorption from aqueous solutions. Biomass Bioenergy 2014, 71, 299-310. [CrossRef]

136. Bayramoglu, G.; Altintas, B.; Arica, M.Y. Adsorption kinetics and thermodynamic parameters of cationic dyes from aqueous solutions by using a new strong cation-exchange resin. Chem. Eng. J. 2009, 152, 339-346. [CrossRef]

137. Liu, C.-C.; Kuang-Wang, M.; Li, Y.-S. Removal of Nickel from Aqueous Solution Using Wine Processing Waste Sludge. Ind. Eng. Chem. Res. 2005, 44, 1438-1445. [CrossRef]

138. Cope, C.O.; Webster, D.S.; Sabatini, D.A. Arsenate adsorption onto iron oxide amended rice husk char. Sci. Total Environ. 2014, 488-489, 554-561. [CrossRef]

139. Zhou, Z.; Liu, Y.-G.; Liu, S.-B.; Liu, H.-Y.; Zeng, G.-M.; Tan, X.; Yang, C.-P.; Ding, Y.; Yan, Z.-L.; Cai, X. Sorption performance and mechanisms of arsenic $(V)$ removal by magnetic gelatin-modified biochar. Chem. Eng. J. 2017, 314, 223-231. [CrossRef]

140. Pokhrel, D.; Viraraghavan, T. Arsenic removal from an aqueous solution by modified A. niger biomass: Batch kinetic and isotherm studies. J. Hazard. Mater. 2008, 150, 818-825. [CrossRef]

141. Chammui, Y.; Sooksamiti, P.; Naksata, W.; Thiansem, S.; Arqueropanyo, O.-A. Removal of arsenic from aqueous solution by adsorption on Leonardite. Chem. Eng. J. 2014, 240, 202-210. [CrossRef]

142. Baig, S.A.; Sheng, T.; Sun, C.; Xue, X.; Tan, L.; Xu, X. Arsenic Removal from Aqueous Solutions Using $\mathrm{Fe}_{3} \mathrm{O}_{4}-\mathrm{HBC}_{\mathrm{H}} \mathrm{Composite}$ Effect of Calcination on Adsorbents Performance. PLoS ONE 2014, 9, e100704. [CrossRef]

143. Lin, L.; Qiu, W.; Wang, D.; Huang, Q.; Song, Z.; Chau, H.W. Arsenic removal in aqueous solution by a novel Fe-Mn modified biochar composite: Characterization and mechanism. Ecotoxicol. Environ. Saf. 2017, 144, 514-521. [CrossRef]

144. Hu, X.; Ding, Z.; Zimmerman, A.; Wang, S.; Gao, B. Batch and column sorption of arsenic onto iron-impregnated biochar synthesized through hydrolysis. Water Res. 2015, 68, 206-216. [CrossRef]

145. Guo, H.; Stüben, D.; Berner, Z.A. Removal of arsenic from aqueous solution by natural siderite and hematite. Appl. Geochem. 2007, 22, 1039-1051. [CrossRef]

146. Turk, T. Removal of Dissolved Arsenic by Pyrite Ash Waste. Mine Water Environ. 2017, 36, 255-263. [CrossRef]

147. Samsuri, W.; Sadegh-Zadeh, F.; Seh-Bardan, B.J. Adsorption of As(III) and As(V) by Fe coated biochars and biochars produced from empty fruit bunch and rice husk. J. Environ. Chem. Eng. 2013, 1, 981-988. [CrossRef]

148. Cedillo, M.J.J.; Olguín, M.; Fall, C.; Colin-Cruz, A. Adsorption capacity of iron- or iron-manganese-modified zeolite-rich tuffs for As(III) and As(V) water pollutants. Appl. Clay Sci. 2011, 54, 206-216. [CrossRef]

149. Baskan, M.B.; Pala, A. Removal of arsenic from drinking water using modified natural zeolite. Desalination 2011, 281, 396-403. [CrossRef]

150. Ho, Y.-S.; Ofomaja, A. Kinetics and thermodynamics of lead ion sorption on palm kernel fibre from aqueous solution. Process. Biochem. 2005, 40, 3455-3461. [CrossRef]

151. Ho, Y.-S.; Ofomaja, A. Effects of calcium competition on lead sorption by palm kernel fibre. J. Hazard. Mater. 2005, 120, 157-162. [CrossRef] [PubMed]

152. Zhang, M.; Gao, B.; Varnoosfaderani, S.; Hebard, A.; Yao, Y.; Inyang, M. Preparation and characterization of a novel magnetic biochar for arsenic removal. Bioresour. Technol. 2013, 130, 457-462. [CrossRef] [PubMed]

153. Kong, S.; Wang, Y.; Hu, Q.; Olusegun, A.K. Magnetic nanoscale Fe-Mn binary oxides loaded zeolite for arsenic removal from synthetic groundwater. Colloids Surf. A Physicochem. Eng. Asp. 2014, 457, 220-227. [CrossRef]

154. Ho, Y.S. Citation review of Lagergren kinetic rate equation on adsorption reactions. Scientometrics 2004, 59, 171-177.

155. Ho, Y.S.; McKay, G. Pseudo-second order model for sorption processes. Process. Biochem. 1999, 34, 451-465. [CrossRef]

156. Jiménez-Cedillo, M.J.; Olguín, M.T.; Fall, C.; Colin-Cruz, A. As(III) and As(V) sorption on iron-modified non-pyrolyzed and pyrolyzed biomass from Petroselinum crispum (parsley). J. Environ. Manag. 2013, 117, 242-252. [CrossRef]

157. Dorraji, M.S.S.; Mirmohseni, A.; Tasselli, F.; Criscuoli, A.; Carraro, M.; Gross, S.; Figoli, A. Preparation, characterization and application of iron (III)-loaded chitosan hollow fiber membranes as a new bio-based As (V) sorbent. J. Polym. Res. 2014, 21, 399. [CrossRef]

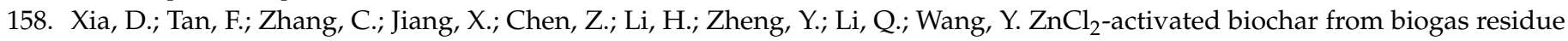
facilitates aqueous As(III) removal. Appl. Surf. Sci. 2016, 377, 361-369. [CrossRef]

159. Mohan, D.; Pittman, C.U.; Bricka, M.; Smith, F.; Yancey, B.; Mohammad, J.; Steele, P.H.; Franco, M.A.; Gómez-Serrano, V.; Gong, H. Sorption of arsenic, cadmium, and lead by chars produced from fast pyrolysis of wood and bark during bio-oil production. $J$. Colloid Interface Sci. 2007, 310, 57-73. [CrossRef] 